\title{
Evolution of Neoproterozoic Wonoka-Shuram Anomaly-aged carbonates: evidence from clumped isotope paleothermometry
}

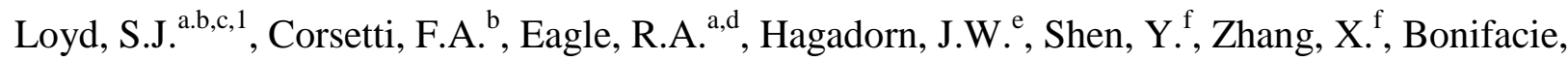
M. ${ }^{\mathrm{g}}$, Tripati, A.K. ${ }^{\mathrm{a}, \mathrm{h}, 1}$

${ }^{\mathrm{a} D e p a r t m e n t ~ o f ~ E a r t h, ~ P l a n e t a r y, ~ a n d ~ S p a c e ~ S c i e n c e s, ~ U n i v e r s i t y ~ o f ~ C a l i f o r n i a, ~ L o s ~ A n g e l e s, ~} 595$ Charles Young Drive East, Los Angeles, CA 90095, USA

${ }^{b}$ Department of Earth Sciences, University of Southern California, 3651 Trousdale Avenue, Los Angeles, CA 90089, USA

${ }^{\mathrm{c}}$ Department of Geological Sciences, California State University, Fullerton, 800 N. State College Blvd., Fullerton, CA 92831, USA.

${ }^{\mathrm{d}}$ Division of Geological and Planetary Sciences, California Institute of Technology, $1200 \mathrm{E}$. California Blvd., Pasadena, CA 91125, USA

${ }^{\mathrm{e}}$ Denver Museum of Nature \& Science, 2001 Colorado Boulevard, Denver, CO 80205, USA

${ }^{\mathrm{f}}$ CAS Key Laboratory of Crust-Mantle Materials and Environments, School of Earth and Space Sciences, University of Science and Technology of China, Hefei 230026, China 
${ }^{g}$ Institut de Physique du Globe de Paris, Equipe de Géochimie des Isotopes Stables, Sorbonne Paris Cité, Université Paris Diderot, UMR 7154 CNRS, F-75005 Paris, France

${ }^{\mathrm{h}}$ Department of Atmospheric and Oceanic Sciences, Institute of the Environment and Sustainability, Institute of Geophysics and Planetary Physics, California Nanosystems Institute, University of California, Los Angeles, 595 Charles Young Drive East, Los Angeles, CA 90095, USA

${ }^{1}$ Corresponding authors:

Sean Loyd, Department of Geological Sciences, California State University, Fullerton, 800 N. State College Blvd., Fullerton, CA 92831, USA. Email: sloyd@ fullerton.edu

Aradhna Tripati, Department of Earth, Planetary, and Space Sciences, University of California, Los Angeles, 595 Charles Young Drive East, Los Angeles, CA 90095, USA. Email: ripple@zephyr.ess.ucla.edu; telephone: 310-206-3531.

Keywords: Neoproterozoic, isotope geochemistry, carbon isotopes, biogeochemistry, clumped isotopes, diagenesis 


\section{Abstract}

The Wonoka-Shuram Anomaly represents the largest negative carbon isotope excursion recognized in the geologic record and is associated with the emergence and diversification of metazoan life ca. 580 million years ago (Ma). The origin of the anomaly is highly debated, with interpretations ranging from primary to diagenetic, each having unique and potentially transformative implications for early life. Here, we apply carbonate clumped isotope thermometry to three sections expressing the anomaly in order to constrain mineral formation temperatures and thus directly calculate water oxygen isotope compositions $\left(\delta^{18} \mathrm{O}_{\mathrm{w}}\right)$ with which carbonate minerals equilibrated. With $\delta^{18} \mathrm{O}_{\mathrm{w}}$ known, it is possible to address previous hypotheses for the origin of the anomaly. In each section, precipitation temperatures correlate positively with reconstructed $\delta^{18} \mathrm{O}_{\mathrm{w}}$. Previous hypotheses, based on the covariance of $\delta^{18} \mathrm{O}_{\text {carb }} \mathrm{vs}$. $\delta^{13} \mathrm{C}_{\text {carb }}$ (uncorrected for temperature effects), suggested a meteoric diagenetic origin for the anomaly. However, reconstructed $\delta^{18} \mathrm{O}_{\mathrm{w}}$ values do not covary with carbon isotope compositions $\left(\delta^{13} \mathrm{C}_{\text {carb }}\right)$ within anomaly facies. Rather, the oxygen isotope and temperature data are consistent with carbonate recrystallization and equilibration under increasingly rock-buffered conditions. Based on simple modeling and comparison to modern formation fluids, recrystallization may have occurred in an environment far removed from the initial depositional or early diagenetic regime. In addition, although clumped isotope temperatures vary significantly and reach elevated values consistent with burial diagenesis, it is unclear to what degree, if at all, carbon isotope values were reset during recrystallization. Ultimately, these new data indicate that Wonoka-Shuramaged carbonates experienced equilibration with fluids under increasingly closed-system conditions. The clumped isotope data do not provide a means to distinguish previous hypotheses 
outright, but provide additional context for the evaluation of geochemical signatures within these ancient carbonate rocks.

\section{INTRODUCTION}

Much of our understanding of the origins of life on the early Earth originates from geochemical signatures incorporated into carbonate rocks. Although carbonate geochemistry can be used to probe ancient surface environments, it is critical to first assess the potential for alteration of primary geochemical signatures, as carbonates are susceptible to post-depositional alteration (i.e., diagenesis). The oxygen isotope compositions of carbonate minerals $\left(\delta^{18} \mathrm{O}_{\text {carb }}\right)$ are widely employed as diagenetic indicators. However, unraveling the specific diagenetic histories using $\delta^{18} \mathrm{O}_{\text {carb }}$ has been a longstanding problem in the geosciences largely due to influences by both temperature and fluid oxygen isotope composition $\left(\delta^{18} \mathrm{O}_{\mathrm{w}}\right)$. The two most common styles of carbonate diagenesis may both drive $\delta^{18} \mathrm{O}_{\text {carb }}$ to lower values. Meteoric diagenesis occurs at shallow depths, through contact primarily with non-marine fluids that are depleted in ${ }^{18} \mathrm{O}$ (Allan and Mathews, 1982). Carbonates formed in contact with meteoric fluids will record low $\delta^{18} \mathrm{O}_{\text {carb }}$ and low carbon isotope compositions $\left(\delta^{13} \mathrm{C}_{\text {carb }}\right)$ due to fluid interaction with soil organic matter (Gross and Tracey, 1966). Burial diagenesis occurs deeper and generally at elevated temperatures. As the incorporation of ${ }^{18} \mathrm{O}$ into the carbonate lattice is temperature dependent, carbonates that grow or are altered at higher temperatures may record depleted $\delta^{18} \mathrm{O}$ values (Kim and O'Neil, 1997). Burial diagenesis can result in signatures that are similar to carbonates influenced by meteoric diagenesis because temperature increases with burial and carbonates 
(such as metastable aragonite and high-magnesium calcite) are susceptible to recrystallization over time (Sandberg, 1975). However, fluid isotope compositions at depth (confounded by varying degrees of rock buffering; e.g., Banner and Hanson, 1990) may be quite different from those of surface environments, therefore carbonates forming in a burial environment may exhibit a wide range in $\delta^{18} \mathrm{O}_{\text {carb }}$ extending to both negative and positive extremes. As a result, interpreting the $\delta^{18} \mathrm{O}_{\text {carb }}$ of ancient rocks as resulting from primary marine precipitation, meteoric diagenesis or burial diagenesis has remained a longstanding problem in carbonate geochemistry.

The origin of one of the most unusual carbon isotope features in the geologic record, the 580 million-year-old Wonoka-Shuram Anomaly, is debated as primary by some (Rothman et al., 2003; Fike et al., 2006; Kaufman et al., 2007) and diagenetic by others (Burns and Matter, 1993; Knauth and Kennedy, 2009; Derry, 2010). The association of the anomaly, the largest negative $\delta^{13} \mathrm{C}_{\text {carb }}$ excursion in Earth's history (Grotzinger et al., 2011), with the emergence and diversification of metazoan life makes it of broad interest. Based on the current understanding of the marine $\delta^{13} \mathrm{C}$ record collected from numerous carbonate platforms around the world, the Neoproterozoic ocean may have experienced some of the most extreme carbon isotope shifts in Earth's history, with positive swings upwards of $\sim+12 \%$ and negative shifts down to $\sim-11 \%$, with the lowest $\delta^{13} \mathrm{C}_{\text {carb }}$ values expressed within the Wonoka-Shuram Anomaly (Halverson et al., 2005) (Fig. 1).

The seemingly global nature of the Wonoka-Shuram Anomaly (see Fig. 1) has led to the development of multiple primary hypotheses to explain its origin. If representative of ancient ocean chemistry, the carbon cycle must have been vastly different from today to allow such massive carbon isotope swings, and there is no shortage of hypotheses to explain them. These include interpretations such as volcanic carbon dioxide buildup linked to extensive glaciation 
(e.g., the "snowball Earth" hypothesis) (Hoffman et al., 1998), the release of methane (Kennedy et al., 2001), the partial oxidation of a large pool of dissolved organic carbon (Rothman et al., 2003), and the weathering of fossil organic matter with increasing oxygen in the atmosphere (Kaufman et al., 2007). In the absence of robust biostratigraphy and adequate radiometric dates, the Wonoka-Shuram and similar excursions form the backbone of carbon isotope chemostratigraphy, an approach that has been widely employed to correlate strata from place to place during this critical time in Earth's history (Knoll, 2000). However, the utility of the carbon isotope chemostratigraphic tool requires that $\delta^{13} \mathrm{C}_{\text {carb }}$ reflect global values.

When interpreting samples of such antiquity, most researchers acknowledge that diagenetic alteration has occurred and that most sequences have likely experienced burial heating (Knauth and Kennedy, 2009; Arthur, 2009; Derry 2010). However, $\delta^{13} \mathrm{C}_{\text {carb }}$ is not strongly temperature dependent (in contrast to $\delta^{18} \mathrm{O}_{\text {carb }}$ ) and should be buffered against drastic change because carbonate rocks contain much more carbon than typical diagenetic fluids (Banner and Hanson, 1990). In contrast, $\delta^{18} \mathrm{O}_{\text {carb }}$ is less likely to be rock-buffered, is strongly temperature dependent as discussed above, and thus altered from primary values more easily through geologic processes (Banner and Hanson, 1990). Recently, diagenetic hypotheses for the Wonoka-Shuram Anomaly have been proposed (Knauth and Kennedy, 2009; Derry 2010,). Meteoric diagenesis in modern carbonate platforms tends to lead to covariation between $\delta^{13} \mathrm{C}_{\mathrm{carb}^{-}}$ $\delta^{18} \mathrm{O}_{\text {carb }}$ (Gross and Tracey, 1966), and a meteoric diagenesis origin of the Wonoka-Shuram Anomaly (and Neoproterozoic $\delta^{13} \mathrm{C}_{\text {carb }}$ excursions in general) was hypothesized based on depleted and positively correlated $\delta^{13} \mathrm{C}_{\text {carb }}$ and $\delta^{18} \mathrm{O}_{\text {carb }}$ values from multiple successions (Knauth and Kennedy, 2009) (Fig. 2). Thus, the depleted and correlated $\delta^{13} \mathrm{C}_{\mathrm{carb}}-\delta^{18} \mathrm{O}_{\text {carb }}$ values observed in Neoproterozoic rocks have been proposed to reflect a more "modern" style of diagenesis 
characterized by fluids containing organically sourced carbon from microbially generated soils on land (Knauth and Kennedy, 2009). If correct, the implications of this meteoric diagenesis hypothesis are profound and require that a relatively extensive, global and microbial terrestrial ecosystem existed in the terminal Neoproterozoic. Furthermore, this hypothesis is in direct opposition to primary hypotheses invoked to explain the Wonoka-Shuram Anomaly (along with ramifications for the origins and evolution of metazoa) and imply that $\delta^{13} \mathrm{C}_{\text {carb }}$ values are not globally representative and therefore provide little chemostratigraphic correlation potential. However, some diagenetic processes may occur at the global scale, depending on the specific mechanism (e.g., glacial drawdown, Swart and Kennedy, 2012).

In order to explore the origin of the Wonoka-Shuram Anomaly, we use a new tool, the carbonate clumped isotope paleothermometer (Ghosh et al., 2006; Dennis and Schrag, 2010) to determine the temperature of mineral formation and therefore better characterize the rocks in which the anomaly is preserved. This thermometer enables us to calculate calcite and dolomite precipitation temperatures independently of the isotopic composition of the water in which the carbonate crystallized (Ghosh et al., 2006; Guo et al., 2009; Dennis and Schrag, 2010). Clumped isotope-derived temperatures can be combined with $\delta^{18} \mathrm{O}_{\text {carb }}$ to uniquely determine $\delta^{18} \mathrm{O}_{\mathrm{w}}$ through application of an appropriate carbonate-water oxygen isotope fractionation factor (Kim and O'Neil, 1997; Vasconcelos et al., 2005). The tool has been used for a range of applications including the study of primary and diagenetic processes in terrestrial and marine samples of a wide range of ages (Came et al., 2007; Affek et al., 2008; Dennis and Schrag, 2010; Eagle et al., 2010, 2011; 2013; Passey et al., 2010; Tripati et al., 2010, 2014; Bristow et al., 2011; Ferry et al., 2011; Finnegan et al., 2011; Huntington et al., 2011; Keating-Bitonti et al., 2011; Loyd et al., 2012a, 2013a; 2014; Passey and Henkes, 2012; Swanson et al., 2012; Dale et al., 2014). 


\section{GEOLOGIC CONTEXT}

Carbonate samples from three Neoproterozoic units that express the Wonoka-Shuram Anomaly (Corsetti and Kaufman, 2003; Jiang et al., 2007; Loyd et al., 2012b) were analyzed for their clumped isotope composition in order to determine the temperatures at which the carbonates precipitated and calculate $\delta^{18} \mathrm{O}_{\mathrm{w}}$, neither of which can be uniquely determined using conventional isotopic techniques. The carbonates were deposited between $\sim 635$ and $\sim 500 \mathrm{Ma}$ and include dominantly shallow water facies exhibiting the Wonoka-Shuram Anomaly (Corsetti and Kaufman, 2003; Jiang et al., 2007; Loyd et al., 2012b) from Sonora Mexico, Death Valley California and South China. The Sonora and Death Valley sections are mixed carbonatesiliciclastic and the South China section is carbonate dominated (Fig. 3). The ages of these units are well-constrained through temporal correlations built upon biostratigraphic, chemostratigraphic and radiometric data (Stewart et al., 1970; Stewart et al., 1984; Christie-Blick and Levy, 1989; Heaman and Grotzinger, 1992; Corsetti and Hagadorn, 2000; Jenkins et al., 2002; Corsetti and Kaufman, 2003; Zhou et al., 2007; Jiang et al., 2007; Sour-Tovar et al., 2007; Loyd et al., 2012b). Figure 3 includes carbon isotope chemostratigraphy and the positions of the Wonoka-Shuram Anomaly (WSA) and the Precambrian-Cambrian boundary for each section, where applicable. Detailed depositional environment interpretations, lithological descriptions and chronologic constraints are provided in previous reports (Corsetti and Kaufman, 2003; Jiang et al., 2007; Loyd et al., 2012b).

\section{METHODS}


Analyzed powders were microdrilled dominantly from micrites interpreted as most representative of the 'primary' phases. Regions containing coarse-crystalline spar and/or clear late-stage crusts were avoided to ensure sampling of the most pristine and representative phases. Carbonates are dominantly monomineralic and composed of limestone or dolostone with one exception (see Table 1). A single sample from the Doushantuo consists of $~ 20 \%$ calcite and $80 \%$ dolomite. The mineralogy of these carbonates was previously reported (Kaufman et al., 2007; Loyd et al., 2012b), and/or determined here via x-ray diffraction.

\section{Stable isotope analysis, standardization, and calculations:}

Between 6 and $14 \mathrm{mg}$ of powdered sample was used for each measurement. A small subset of homogenized samples were measured in duplicate in order to evaluate sample heterogeneity, with data reported in Table 1. Sample powders were digested in phosphoric acid at $90^{\circ} \mathrm{C}$ and analyzed following a published protocol (Huntington et al., 2009; Passey et al., 2010). The product $\mathrm{CO}_{2}$ was analyzed on a specially modified Thermo MAT 253 gas source mass spectrometer dedicated to measuring clumped isotopes in $\mathrm{CO}_{2}$ at UCLA. A custom-built, automated, online device (Passey et al., 2010) is used to introduce samples to the mass spectrometer. It is composed of 1) a Costech Zero Blank autosampler made of stainless steel that will pull high vacuum, 2) a common acid bath for phosphoric acid digestion of samples, 3) cryogenic traps (dry ice and ethanol, and liquid nitrogen) for the purification and collection of $\mathrm{CO}_{2}$ and removal of water and other gases with low vapor pressures, 4) a gas chromatograph with a packed column and a cryogenic trap to further purify $\mathrm{CO}_{2}$ through the removal of organic contaminants, with helium being used as a carrier gas, 5) cryogenic traps to separate the $\mathrm{CO}_{2}$ 
from the helium, and 6) a final set of valves and traps to purify $\mathrm{CO}_{2}$ and transfer it into the bellows of the mass spectrometer.

Mass spectrometers used for analyses are configured specifically to measure multiply substituted isotopologues of $\mathrm{CO}_{2}$, housing an array of Faraday cups that simultaneously measure cardinal masses 44, 45, 46, 47, 48, and 49 AMU. The detectors for masses 44, 45, and 46 are registered through $3 \times 10^{8}, 3 \times 10^{10}$, and $10^{11}$ Ohm resistors, respectively, while the channels for masses 47-49 are registered with $10^{12}$ Ohm resistors. Measurements are made to yield a stable 16-volt signal for mass 44 , with peak centering, background $\mathrm{CO}_{2}$ measurement, and pressure balancing before each acquisition. Each sample and standard analysis is performed for 8 acquisitions.

$25^{\circ} \mathrm{C}$ water-equilibrated gases and 'heated gases' are analyzed regularly. Heated gases are composed of $\mathrm{CO}_{2}$ with a stochastic distribution of isotopes among isotopologues. Gases with different bulk $\delta^{18} \mathrm{O}$ and $\delta^{13} \mathrm{C}$ ratios in quartz breakseals are heated to $1000^{\circ} \mathrm{C}$ for two hours and then quenched at room temperature. These heated gases and $25^{\circ} \mathrm{C}$ water-equilibrated gases are then purified and analyzed using the same protocol as sample gases, and used to construct the absolute reference frame and determine a non-linearity correction as described elsewhere (Dennis et al., 2011).

Clumped isotope values are reported in $\Delta_{47}$ notation, referring to the $\%$ enrichment of ${ }^{13} \mathrm{C}^{18} \mathrm{O}^{16} \mathrm{O}$ produced during acid digestion of carbonates above the amount expected for a random distribution of isotopes amongst all $\mathrm{CO}_{2}$ isotopologues. Specifically $\Delta_{47}$ is defined as:

$$
\Delta_{47}=\frac{R^{47}}{2 R^{13} R^{18}+2 R^{17} R^{18}+R^{13}\left(R^{17}\right)^{2}}-\frac{R^{46}}{2 R^{18}+2 R^{13} R^{17}+R^{13}\left(R^{17}\right)^{2}}-\frac{R^{45}}{R^{13}+2 R^{17}}+1
$$


where $\mathrm{R}$ is the number ratio, the number of a minor isotopologue to the number of the major isotopologue. All $\Delta_{47}$ values are reported on the absolute reference frame (ARF), which is calculated using 25 and $1000^{\circ} \mathrm{C}$ equilibrated gases (Dennis et al., 2011). Long-term external reproducibility of carbonate standards is $0.009 \%$ ( 1 s.e.). Typical sample precision based on replicate measurements of carbonate samples from this study is $0.020 \%$ ( 1 s.d.) and $0.014 \%$ o (1 s.e.).

Data are shown in Table 1 . These $\Delta_{47}$ values were converted to temperature using the same procedure as a previous study (Bristow et al., 2011) by applying an acid digestion fractionation factor to account for digestion at $90^{\circ} \mathrm{C}$ and using theoretical calibrations (Guo et al., 2009). Published empirical calibrations extend from $1-65^{\circ} \mathrm{C}$ (Ghosh et al., 2006; Dennis et al., 2011; Zaarur et al., 2013; Tang et al., 2014), and application to these samples would require a large extrapolation well beyond this temperature range. We note the trends and absolute values of the theoretical calibration are supported by a high-temperature calibration for synthetic and natural dolomites from $25-350^{\circ} \mathrm{C}$ (Bonifacie et al., 2010). Thus, we use the theoretical calibrations as they allow reconstructions over a large temperature range and take potential differences between dolomites and calcites into account.

The mineral-specific equations used are:

Calcite $\Delta_{47}=-3.33040 \times 10^{9} / \mathrm{T}^{4}+2.32415 \times 10^{7} / \mathrm{T}^{3}-2.91282 \times 10^{3} / \mathrm{T}^{2}-5.54042 / \mathrm{T}+0.23252$

Dolomite $\Delta_{47}=-3.31467 \times 10^{9} / \mathrm{T}^{4}+2.29414 \times 10^{7} / \mathrm{T}^{3}-2.38375 \times 10^{3} / \mathrm{T}^{2}-5.71692 / \mathrm{T}+0.21502$ 
where $\mathrm{T}$ represents temperature in Kelvin.

Fluid oxygen isotope compositions $\left(\delta^{18} \mathrm{O}_{\mathrm{w}}\right)$ are calculated by applying clumped isotope temperatures to the carbonate $\delta^{18} \mathrm{O}$-temperature equations (Kim and O'Neil, 1977, Vasconcelos et al., 2005). The equations used are:

$$
\begin{aligned}
& 1000 \ln \alpha_{\text {calcite-water }}=\left(18.03 \times 10^{3}\right) \mathrm{T}^{-1}-32.42 \\
& 1000 \ln \alpha_{\text {dolomite-water }}=\left(2.73 \times 10^{6}\right) \mathrm{T}^{-2}+0.26
\end{aligned}
$$

where T represents the precipitation temperature in degrees Kelvin, and $\alpha_{\text {calcite-water }}$ and $\alpha_{\text {dolomite- }}$ water are the oxygen isotope fractionation factors between calcite and water and dolomite and water, respectively.

Carbonate $\delta^{13} \mathrm{C}$ values are reported in \%o relative to the VPDB standard. Carbonate $\delta^{18} \mathrm{O}$ values are reported in \%o compared to the VSMOW or VPDB standard as indicated in the text and figures. $\delta^{18} \mathrm{O}_{\mathrm{w}}$ is reported in \%o compared to the VSMOW standard. The reproducibility of carbonate $\delta^{13} \mathrm{C}$ and $\delta^{18} \mathrm{O}$ are generally better than $\pm 0.010 \%$ ( 1 s.d.) for replicate samples and 0.005\% (1 s.e.) for standards (long-term external precision).

\section{RESULTS}

As has been recognized in Wonoka-Shuram-aged carbonates elsewhere, units from Sonora and South China exhibit positively correlated $\delta^{13} \mathrm{C}_{\text {carb }}$ and $\delta^{18} \mathrm{O}_{\text {carb }}$ values (Fig. 2). In contrast, Death Valley carbonates do not express a strong correlation $\left(\mathrm{R}^{2}\right.$ values approach zero and are not significantly correlated at the $95 \%$ confidence level). Each of the three localities yield stratigraphic trends in $\delta^{13} \mathrm{C}_{\text {carb }}$ consistent with similarly aged units globally, with prominent 
negative excursions extending down to $\sim-10 \%$ occurring in facies tens to hundreds of meters below the Precambrian-Cambrian boundary (Fig. 3). These excursions have been correlated to the Wonoka-Shuram Anomaly in previous studies (Corsetti and Kaufman, 2003; Jiang et al., 2007; Loyd et al., 2012b). Among all sections, $\Delta_{47}$ values range from $0.265 \%$ ( \pm 0.010$)$ to 0.579 $( \pm 0.035)( \pm$ values $=1$ s.e. $)$, corresponding to reconstructed temperatures ranging between $\sim 40$ and $370^{\circ} \mathrm{C}$ (Table 1). Sonora, Death Valley and South China carbonates exhibit precipitation temperatures ranging from 58 to $366^{\circ} \mathrm{C}, 49$ to $183^{\circ} \mathrm{C}$ and 38 to $164^{\circ} \mathrm{C}$, respectively. Clumped isotope temperatures show no systematic trend with stratigraphic height in any section (Fig. 3). Calculated $\delta^{18} \mathrm{O}_{\mathrm{w}}$ values from all localities range from -6.2 to $+18.9 \%$ VSMOW (Table 1). Carbonates of Sonora, Death Valley and South China yield $\delta^{18} \mathrm{O}_{\mathrm{w}}$ values ranging from -6.2 to $+18.9 \%$, -6.1 to $+10.3 \%$, and -4.0 to $+11.3 \%$, respectively. Reconstructed carbonate precipitation temperatures and $\delta^{18} \mathrm{O}_{\mathrm{w}}$ values show strong positive correlation (Figs. 4-7, Supplementary Table 1) in nearly all sample groupings. The groupings are site-specific and include samples from the entire stratigraphic section, separated by excursion and non-excursion facies, and separated by dolomite and calcite facies (see Table 1 and Supplementary Table 1). Clumped isotope temperatures are correlated with $\delta^{18} \mathrm{O}_{\text {carb }}$ values in carbonates from the entire stratigraphic section at each locality (Figs. 5-7, Supplementary Table 1). $\delta^{18} \mathrm{O}_{\mathrm{w}}$ and $\delta^{13} \mathrm{C}_{\text {carb }}$ values generally show little correlation in units within each of the three localities and are not correlated in Wonoka-Shuram Anomaly facies (Fig. 8, Supplementary Table 1).

Temperature and oxygen isotope $\left(\delta^{18} \mathrm{O}_{\text {carb }}\right.$ and $\left.\delta^{18} \mathrm{O}_{\mathrm{w}}\right)$ data are plotted over a water-rock model (developed by Banner and Hanson, 1990) in Figures 5-7. The model allows for the generation of temperature-isotope trajectories for the evolution of carbonate minerals and fluids in equilibrium at variable water-rock ratios (W/R). A similar approach was used to explore 
clumped isotope temperature and isotope relationships of diagenetic calcites within an Eocene limestone (Huntington et al., 2011). The Neoproterozoic units explored here exhibit similar trends, with temperature and oxygen values that conform to those expected for mineral reequilibration with increased temperature at relatively low W/R (Figs. 5-7). Specifically, the models that best fit the data correspond to systems with initial $\delta^{18} \mathrm{O}_{\text {carb }}$ values near modern marine limestones (31\%。 VSMOW or $\sim 0 \%$ VPDB) and depleted fluid values ( -10 to $-15 \%$ o VSMOW). Additional information concerning model construction including additional input parameters is included in the Supplementary Information.

\section{DISCUSSION}

\subsection{Closed System Evolution}

The correlations between $\Delta_{47}$-temperature and $\delta^{18} \mathrm{O}_{\mathrm{w}}$, and between $\Delta_{47}$-temperature and $\delta^{18} \mathrm{O}_{\text {carb }}$ likely indicate that these rocks consist of various amounts of carbonate recrystallized and reequilibrated under increasingly closed-system conditions. The ranges of reconstructed temperature and $\delta^{18} \mathrm{O}_{\mathrm{w}}$ overlap with known surface and subsurface geologic environments (Fig. 9; Clayton et al., 1966; Allan and Mathews, 1982; Egeberg and Aagaard, 1989; Clark and Fritz, 1997). The temperatures recorded in Death Valley and South China carbonates lie well within those that would have been reached at maximum burial, as constrained by the thickness of overlying strata: in both Death Valley and South China $\sim 4-7 \mathrm{~km}$ of rock overlies the excursion facies (Stewart, 1966; Jiang et al., 2006), implying possible maximum burial temperatures of up to $\sim 200^{\circ} \mathrm{C}$ (assuming a geothermal gradient of $25^{\circ} \mathrm{C} / \mathrm{km}$ ). In northwestern Mexico, the overlying strata thickness has not been quantified beyond the Cambrian, and therefore maximum burial depths cannot be independently assessed. 
In addition to the positive correlation between $\Delta_{47}$-temperature and $\delta^{18} \mathrm{O}_{\mathrm{w}}$, important information resides in the absolute values of the recurring trend. The low temperature endmembers of $\sim 40^{\circ} \mathrm{C}$ correspond to $\delta^{18} \mathrm{O}_{\mathrm{w}}$ values that range from modern marine values down to $-6 \%$ consistent with modern meteoric fluids (Figs. 5-7, 9). Indeed, the modeled trajectories presented in Figs. 5-7 best fit the data if the initial compositions of recrystallizing fluids are significantly depleted in ${ }^{18} \mathrm{O}$. The trends extend from low-temperature, low- $\delta^{18} \mathrm{O}_{\mathrm{w}}$ values to elevated temperatures and higher- $\delta^{18} \mathrm{O}_{\mathrm{w}}$, likely reflecting variable mineral recrystallization during burial. These burial environments typically exhibit elevated $\delta^{18} \mathrm{O}_{\mathrm{w}}$ values due to waterrock interaction at decreasing W/R (Banner and Hanson, 1990).

\subsection{Environment of Reequilibration}

The temperature- $\delta^{18} \mathrm{O}_{\mathrm{w}}$ values derived from the carbonates explored in this study overlap with data sourced from formation fluids extracted from subsurface reservoirs (Figs. 4, 9). Modern formation fluids are largely interpreted to have experienced increased $\delta^{18} \mathrm{O}$ values during increased water-rock interaction with increasing temperatures (Hitchon and Friedman, 1969; Knauth, 1988; Banner et al., 1989; Egeberg and Aagaard, 1989; Connolly et al., 1990; Pauwels et al., 1993; Moldovanyi et al., 1993; Wilson and Long, 1993). Interestingly, the isotope values recorded in modern systems require isotopically depleted initial fluid $\delta^{18} \mathrm{O}$ compositions. However, these modern systems are far removed from the original marine depositional or early diagenetic environment. Similarly, reequilibration of the Neoproterozoic units examined here likely occurred in an environment far removed from the primary marine and/or early diagenetic regimes. Paleogeographic reconstructions place the continental margin Sonora and Death Valley successions very near the paleoequator (Grotzinger et al., 2011). Low latitude, near-shore 
environments generally exhibit meteoric waters with relatively enriched $\delta^{18} \mathrm{O}_{\mathrm{w}}$ values compared to higher latitude, continental interiors (Fig. 9). Equatorial meteoric fluids rarely exhibit isotope depletions greater than 5\%o compared to marine values (Yurtsever and Gat, 1981; Rozanski et al., 1993; Gat, 1996). In contrast, interior continental waters exhibit isotope compositions that often extend down to -10 to $-15 \%$, consistent with the initial fluid compositions implied by the W/R model results (Figs. 5-7, 8). In fact, modern precipitation $\delta^{18} \mathrm{O}_{\mathrm{w}}$ values of Sonora, Death Valley and South China are similar to those suggested by the W/R model (Barry and Chorley, 1987; Rozanski et al., 1993). Therefore, the initial geochemical signals have been variably overprinted by later diagenesis and reconstructed $\delta^{18} \mathrm{O}_{\mathrm{w}}$ values are not reflective of primary precipitation nor early diagenesis.

The higher end-member temperature and $\delta^{18} \mathrm{O}_{\mathrm{w}}$ values recorded in the Neoproterozoic units likely reflect similar rock-buffered evolution at higher temperatures. Modern fluids may exist that overlap with the higher end-member values reconstructed from isotope data of the Neoproterozoic carbonates, but have not yet been discovered due to logistical complications associated with extraction and analysis of deep/hot fluids. An alternate possibility is that these carbonates have been subjected to solid-state reordering, in which minerals evolve toward higher clumped isotope temperatures in the absence of fluids. Such processes would add doubt to the absolute $\delta^{18} \mathrm{O}_{\mathrm{w}}$ values and are discussed further in the next section.

\subsection{Addressing Overprinting and Non-Temperature Related Effects on $\Delta_{47}$}

Kinetic isotope effects on clumped isotope signatures in carbonates have been reported. Specifically vital effects in tropical Porites corals (Ghosh et al., 2006, Saenger et al., 2012) and 
disequilibrium signatures associated with $\mathrm{CO}_{2}$ degassing in speleothem carbonates (Affek et al., 2008, Daeron et al., 2011) have been recognized. However, these and similar scenarios wherein kinetic isotope effects on clumping in carbonates are observed still encompass 'exceptions' rather than the 'rule'. Nevertheless, it is necessary to discuss the relevance of these and other kinetic isotope effects in the context of the carbonates analyzed in this study. The nontemperature dependent phenomena exhibited by Porites corals likely results from vital effects that do not occur in abiogenic carbonates, similar to those examined here. Whereas a biotic origin for the micrites analyzed here is feasible, published data for micrites (Huntington et al., 2010) agree well with equilibrium clumped isotope signatures. Furthermore, we find no evidence for biogenicity in the examined Neoproterozoic micrites, and the ages of these units preclude the possible incorporation of Porites-sourced carbonates.

Similar arguments as those presented in another publication (Bristow et al., 2011) are relevant to this study and indicate that end-member mixing probably did not overprint an equilibrium clumped isotope signature in some Neoproterozoic successions. Mixing can be discounted as it would require end-member solutions or carbonate minerals with extremely exotic bulk isotope compositions (much greater than $\pm 20 \%$ ) and there is no evidence for such exotic carbonate minerals or former fluids in these Neoproterozoic successions.

In addition to non-temperature effects, it is important to discuss the potential for solidstate reordering to alter $\Delta_{47}$ values without bulk recrystallization (Dennis and Schrag, 2010; Passey and Henkes, 2012; Henkes et al., 2014). Solid-state reordering is a temperature- and timedependent phenomena that may influence the clumped isotope signature without changing other carbonate geochemical signatures, rendering a difference in the signal inheritance timing. Solid state reordering has been shown to be influential in carbonates that have experienced heating 
above $\sim 100^{\circ} \mathrm{C}$ for periods of $10^{6}-10^{8}$ years (Henkes et al., 2014). Solid-state reordering can yield a positive correlation between clumped isotope-based estimates of temperature and $\delta^{18} \mathrm{O}_{\mathrm{w}}$, due to the dependence of $\delta^{18} \mathrm{O}_{\mathrm{w}}$ on temperature (see equations 3 and 4 above). Here, we test for the influence of solid state reordering in two ways: 1) comparison to burial depth, where more influence would be expected with increasing depth/temperature, and 2) covariance with other geochemical parameters, where samples influenced by solid state reordering should not reveal a covariance in other geochemical parameters (e.g., bulk isotopic or trace element composition).

Burial heating induced solid-state reordering would tend to be most severe at the bottom of sedimentary successions where burial depth and temperatures were greatest, and should be particularly evident in kilometer-thick stratigraphic sequences, like the ones analyzed in this study. Figure 3 reveals no systematic relationship between stratigraphic height and clumped isotope temperatures for a given lithology, potential evidence against significant reordering. In addition very closely spaced samples of similar textural and mineralogical character exhibit wide-ranging temperatures, an unlikely consequence of solid-state reordering where signal homogenization is expected. A caveat is that ultimately, due to mineral- and phase-specific behavior of the reordering process (Passey and Henkes, 2012), solid-state reordering may not produce straightforward trends (i.e., with stratigraphic level, and/or between closely-spaced samples) such as those predicted above.

In a situation where heating of a mineral upon burial causes reordering of ${ }^{13} \mathrm{C}-{ }^{18} \mathrm{O}$ bonds without recrystallization it should only affect measured $\Delta_{47}$ values and not bulk isotopic or elemental compositions, and thus may be a more robust test versus stratigraphic thickness. Alternate carbonate geochemical parameters (e.g., $\delta^{13} \mathrm{C}_{\text {carb }}, \delta^{18} \mathrm{O}_{\text {carb }}$, iron concentrations, manganese concentrations, and strontium concentrations) cannot change without elemental 
exchange with fluids during recrystallization. Therefore, any correlation observed between clumped isotope-based temperatures and one of these geochemical parameters likely indicates that the clumped isotope signatures reflect true signals (i.e., primary precipitation and/or recrystallization signals) and not pervasive overprinting by solid-state reordering. Threecomponent mixing may also be identifiable in cross plots, although we acknowledge that variable end-member compositions, the presence of multiple phases, and the occurrence of both mixing and solid-state reordering may complicate the interpretation of data using this framework.

The observed correlations between temperature and $\delta^{18} \mathrm{O}_{\text {carb }}$ for the successions surveyed in this study (Figs. 5-7, Supplementary Table 1) are consistent with a lack of pervasive solid state reordering. Although solid-state reordering is likely phase- and texture-specific (Passey and Henkes, 2014), the similarity of our samples with respect to grain size and texture may promote similar behavior in response to reordering. If true, then the data can be most simply explained if the signals recorded in these Neoproterozoic carbonates reflect evolution under increasingly rock-buffered conditions at elevated temperatures.

\subsection{Implications for the Wonoka-Shuram Excursion}

Although these rocks consist of variably recrystallized carbonates, we can still assess the potential for clumped isotopes to provide insight into the Wonoka-Shuram hypotheses by specifically examining samples from excursion-containing facies (including those with bulk stable isotope signatures that exhibit correlated $\delta^{13} \mathrm{C}_{\text {carb }}$ and $\delta^{18} \mathrm{O}_{\text {carb }}$ values). The proposed diagenetic hypotheses are predicated to have different dominant initial controls on $\delta^{18} \mathrm{O}_{\text {carb}}$, namely $\delta^{18} \mathrm{O}_{\mathrm{w}}$ (the meteoric hypothesis, Burns and Matter, 1993; Knauth and Kennedy, 2009) 
and fluid mixing at moderate water/rock values and elevated temperature (the burial hypothesis, Derry, 2010). Below, we address these controls using clumped isotope data in addition to the potential for rock buffering to preferentially retain certain geochemical signatures. We note that if substantial amounts of solid-state reordering had occurred, this would result in the calculation of spuriously elevated $\delta^{18} \mathrm{O}_{\mathrm{w}}$ values.

5.4.1 The meteoric diagenetic hypothesis: The lack of a correlation between $\delta^{13} \mathrm{C}_{\text {carb }}$ and $\delta^{18} \mathrm{O}_{\mathrm{w}}$, particularly in Wonoka-Shuram Anomaly facies, is compelling evidence against preservation of a strictly meteoric diagenetic signal (Figs. 5-7, Supplementary Table 1). Because of the differential influence of diagenesis in rock-buffered settings, it is possible that the $\delta^{13} \mathrm{C}_{\text {carb }}$ was imparted during meteoric diagenesis and subsequently retained and only the $\delta^{18} \mathrm{O}_{\text {carb }}$ was reset during burial diagenesis and serendipitously record similarly depleted isotopic values. The water rock models depicted in Figs. 5-7 suggest that reequilibration involved fluids with initial isotopic values of $\sim-10$ to $-15 \%$ VSMOW, similar to modern meteoric waters currently existing at each locality, but perhaps somewhat more depleted than would be expected for low latitude meteoric waters where the strata were originally deposited (Fig. 8). However, these fluids may not have contained the appreciable organically derived dissolved inorganic carbon necessary to produce an excursion in carbonate rocks down to $\sim-10 \%$ VPDB. In Death Valley and Sonora, where the samples have been examined petrographically in detail (e.g., Corsetti and Kaufman, 2003; Pruss et al., 2008; Loyd et al., 2012b; 2013b), micrite and pseudomorphs of formerly aragonite seafloor fan facies occur in the nadir of the Wonoka-Shuram Anomaly which lack meteoric diagenetic indicators (e.g., preferential dissolution of formerly aragonite phases, dissolution surfaces, equant sparry calcite cements, meniscus or pendant cements, etc.). 
The Neoproterozoic carbonates examined here exhibit $\Delta_{47}$ and $\delta^{18} \mathrm{O}_{\mathrm{w}}$ values consistent with reequilibration at significant depths and do not appear to strictly record near-surface conditions (primary or diagenetic). Furthermore, these results emphasize that the utility of carbonate $\delta^{13} \mathrm{C}$ and $\delta^{18} \mathrm{O}$ cross plots in diagenetic studies for the Neoproterozoic (and for other time intervals) is diminished if 1) the isotopic compositions of samples were attained at different times and 2) the potential burial diagenetic regime is insufficiently characterized.

5.4.2 The burial diagenetic hypothesis: At face value, a burial diagenetic origin for the Wonoka-Shuram Anomaly appears attractive given the propensity for old rocks to experience burial heating. Indeed, the clumped isotope data presented here confirm high-temperature recrystallization of some carbonates, a particularly reassuring finding. Similar linear and positively correlated $\delta^{13} \mathrm{C}_{\text {carb }}$ and $\delta^{18} \mathrm{O}_{\text {carb }}$ arrays as those exhibited by purported Wonoka-Shuram Anomaly carbonates can develop from mixing of fluids at relatively high temperatures during burial diagenesis (Derry, 2010). Derry (2010) produced such isotope trends through fluid mixing at elevated but constant temperatures. A singular temperature would be expected to adequately characterize a single diagenetic event. However, the clumped isotope data reported here suggests a wide range in precipitation temperatures in both excursion and non-excursion containing units. These data indicate diagenetic reequilibration across a range of temperatures. Regardless, the high clumped isotope temperatures suggest significant recrystallization in the burial realm and do not preclude a mixing-style signal as envisioned by Derry (2010). In fact, a similar rock buffering argument as proposed to preserve an initial meteoric diagenesis signal (and a primary signal for that matter) may apply to a relatively shallow burial diagenetic signal as well. At this point, it is unclear whether or not mixing of many phases precipitated at different temperatures 
and under variable water/rock ratios could produce the quasi-linear $\delta^{13} \mathrm{C}_{\mathrm{carb}}-\delta^{18} \mathrm{O}_{\text {carb }}$ arrays exhibited by many Wonoka-Shruam carbonates, or if buffering of a signal generated by mixing at a single temperature is required.

5.4.3 Primary hypotheses: Many lines of evidence support a primary origin for the WonokaShuram Anomaly (Grotzinger et al., 2011). The global expression of the excursion, with little scatter and a characteristic shape repeated in many sections around the world, is highly suggestive of a primary origin (Grotzinger et al., 2011) and is difficult to reconcile through burial diagenesis. The striking consistency of the excursion magnitude (down to $\sim-12 \%$ ) is problematic to explain in diagenetic environments where high spatial heterogeneity is typically the norm and where a control on the maximum depletion in $\delta^{13} \mathrm{C}_{\text {carb }}$ is difficult to envision. In addition, the contribution of carbon originally sourced from organic matter would have been quite significant, depending on the isotopic composition of organic matter and the original carbonate sediment. If the primary carbonate sediment exhibited a carbon isotopic composition of $\sim 0 \%$ (VPDB) similar to the modern ocean and the organic matter expressed an isotopic composition of $\sim-25 \%$, approximately half of the final rock carbon must have been derived from organic matter. Whereas it seems reasonable that porous, thin carbonate lenses could contain enough secondary cement to satisfy this mass balance, thick carbonate packages occur in all sections examined here (Fig. 3). Indeed, Pleistocene platform deposits that record depleted $\delta^{13} \mathrm{C}_{\text {carb }}$ as the result of meteoric diagenesis during glacial drawdown do not extend down to the values expressed in the Wonoka-Shuram Anomaly (Swart and Kennedy, 2012). The asymmetry of the excursion (Fig. 1) is evidence for a primary oceanic process in which the recovery of the whole ocean system would have likely required an extended period of time (perhaps millions of 
years; Le Guerroue et al., 2006) to return to pre-excursion $\delta^{13} \mathrm{C}$ values. The asymmetry expressed in Pleistocene platform deposits shows more drastic isotope depletion up-section (Swart and Kennedy, 2012), rather than the rapid initial depletion in $\delta^{13} \mathrm{C}$ followed by a gradual increase up-section as expressed in Wonoka-Shuram carbonates (Fig. 1). Although diagenetic processes are likely to produce some of the isotopically depleted carbonates of the Neoproterozoic (and other time periods), many characteristics of the Wonoka-Shuram Anomaly are inconsistent with such an origin.

In addition, recent sulfur isotope investigations have uncovered a nearly global positive correlation between $\delta^{13} \mathrm{C}_{\text {carb }}$ and carbonate-bound, trace sulfate $\delta^{34} \mathrm{~S}$ (Loyd et al., 2013b). Such a correlation is difficult to generate from strictly diagenetic processes in a burial or meteoric setting, largely because these fluids are generally very low in dissolved sulfate. Ultimately, the positive correlation between $\delta^{13} \mathrm{C}_{\text {carb }}$ and $\delta^{18} \mathrm{O}_{\text {carb }}$ (a feature not expressed at all locales, Death Valley data presented here and new data from Oman, Lee et al., 2013) is the major detractor of a primary origin as it is difficult to reconcile in primary oceanic settings.

Ultimately, the new data presented here do not directly support any singular origin for the Wonoka-Shuram carbon isotope excursion, primary or diagenetic. Rather, these data indicate that these old carbonate rocks experienced reequilibration at high temperatures, under low W/R conditions and likely far removed from the initial environment of deposition, as evidenced in part by comparison with modern subsurface fluids. The carbon isotope excursion and general correlation between $\delta^{13} \mathrm{C}_{\text {carb }}$ and $\delta^{18} \mathrm{O}_{\text {carb }}$ remains problematic and any argument to explain its origin must allow for signal inheritance or retention through carbonate reequilibration in environments far removed from Earth's surface. 


\section{Conclusions}

Carbonate clumped isotope data from Wonoka-Shuram Anomaly-containing successions of Sonora, Mexico, Death Valley, USA and South China indicate wide-ranging precipitation temperatures, extending from $\sim 40$ to $370{ }^{\circ} \mathrm{C}$. Reconstructed $\delta^{18} \mathrm{O}_{\mathrm{w}}$ values extend from depleted $(\sim-6 \%)$ to highly enriched $(\sim+19 \%)$ compared to the modern average ocean. These data suggest that carbonate recrystallization occurred across a range of temperatures that overlap quite well with modern subsurface fluids that have experienced significant water-rock interaction. Carbonate carbon isotope values express no significant correlations with $\delta^{18} \mathrm{O}_{\mathrm{w}}$, whereas clumped isotope temperatures show significant correlations with $\delta^{18} \mathrm{O}_{\text {carb }}$. These data require that any meteoric diagenesis origin must have survived subsequent recrystallization (potentially through rock buffering). The wide range in precipitation temperatures precludes a singular burial digenetic event as previously modeled (Derry, 2010), however similar modeling over a range of temperatures may provide similar isotope correlations. These data do not provide direct evidence in support of a primary origin for the Wonoka-Shuram Anomaly, but instead support the hypothesis that rocks of such antiquity likely experienced variable reequilibration at high temperatures. Ultimately, any hypothesis attempting to explain the origin (primary or diagenetic) must account for such evolutions. At any rate, the outstanding hypotheses, primary or diagenetic, are problematic by themselves and fail to account for all of the characteristics displayed in Wonoka-Shuram Anomaly carbonates.

Author contributions: SL, RE, and AT conducted clumped isotope analyses. SL, FC, RE, YS, $\mathrm{XZ}$ and AT contributed to additional stable isotope analyses. SL, FC, JH, YS and XZ contributed to sample collection. All authors contributed to the writing of the manuscript. 
Acknowledgments: We would like to thank Tripati Lab Group members including Nam Lai for assistance with sample preparation and mass spectrometric analysis, John Eiler for instrument access for intercalibration, and Pedro Marenco for input. We acknowledge support to SL and AT from the Agouron Institute. This work was funded by National Science Foundation grants ARC1215551 to RAE and AT, EAR-1024929 which supported RAE, and EAR-0949191, EAR1325054, and EAR-1352212 to AT, and Department of Energy BES award DE-SC0010288 to AT, and American Chemical Society (grant \# 51182-DNI2) to AT. In addition, FC acknowledges support from the NASA Exobiology program, YS received funding by the National Natural Science Foundation of China (NNSFC 41025011).

\section{References}

Affek, H., Bar-Matthews, M., Ayalon, A., Matthews, A., Eiler, J. (2008) Glacial/interglacial temperature variations in Soreq cave speleothems as recorded by "clumped isotope" thermometry. Geochimica et Cosmochimica Acta 72, 5351-5360.

Allan, J.R., Matthews, R.K. (1982) Isotope signatures associated with early meteoric diagenesis. Sedimentology 29, 797-817.

Arthur, M.A. (2009) Biogeochemistry: Carbonate rocks deconstructed. Nature 460, 698-699.

Banner, J.L., Hanson, G.N. (1990) Calculation of simultaneous isotopic and trace element variations during water-rock interaction with applications to carbonate diagenesis. Geochim Cosmochim Acta 54, 3123-3137. 
Banner, J.L., Wassergurg, G.J., Dobson, P.F., Carpenter, A.B., Moore, C.H. (1989) Isotopic trace element constraints on the origin and evolution of saline groundwaters from central Missouri. Geochimica et Cosmochimica Acta 53, 383-398.

Barry, R.G., Chorley, R.J. (1987) Atmosphere Weather and Climate, $5^{\text {th }}$ ed., Methuen, 460 p.

Bonifacie, M., Ferry, J.M., Horita, J., Vasconcelos, C., Passey, B.H., Eiler, J.M. (2010)

Calibration and applications of the dolomite clumped isotope thermometer to high temperatures, Goldschmidt Conference Abstract, Knoxville, Tennessee, June 13-18.

Bristow, T. F., Bonifacie, M., Derkowski, A., Eiler J. M., Grotzinger, J. P. (2011) A hydrothermal origin for isotopically anomalous cap dolostone cements from south China, Nature 474, 68-71.

Burns, S.J., Matter, A. (1993) A Carbon isotopic record of the latest Proterozoic from Oman. Eclogae Geol Helvetiae 86, 595-607.

Came, R. E., Eiler J. M., Veizer, J., Azmy, K., Brand, U., Weidman, C. R. (2007) Coupling of surface temperatures and atmospheric $\mathrm{CO} 2$ concentrations during the Palaeozoic era. Nature 449, 198-201.

Christie-Blick, N., Levy, M. (1989) Stratigraphic and tectonic framework of upper Proterozoic and Cambrian rocks in the Western United States, in Christie-Blick, N., Levy, M., Mount, J.F., Signor, P.W., Link, P.K., eds., Late Proterozoic and Cambrian Tectonics, Sedimentation, and Record of Metazoan Radiation in the Western United States: Pocatello, Idaho, to Reno, Nevada 20-29 July, 1989, (American Geophysical Union, 1989), 7-21.

Corsetti, F.A., Kaufman, A.J. (2003) Stratigraphic investigations of carbon isotope anomalies and Neoproterozoic ice ages in Death Valley, California. Geol Soc Am Bull 115, 916-932. 
Corsetti, F. A., Hagadorn, J. W. (2000) Precambrian-Cambrian transition: Death Valley, United States. Geology 28, 299-302.

Clark, I.D., Fritz P. (1997) Environmental Isotopes in Hydrogeology (Taylor \& Francis, CRC Press).

Clayton, R.N., Friedman, I., Graf, D.L., Mayeda, T.K., Meents, W.F., Shrimp, N.F. (1966) The origin of saline formation waters: 1. Isotopic composition. J Geophys Res 71, 3869-3882.

Connolly, C.A., Walter, L.M., Baadsgaard, H., Longstaffe, F.J. (1990) Origin and evolution of formation waters, Alberta Basin, Western Canada Sedimentary Basin. II. Isotope systematics and water mixing. Applied Geochemistry 5, 397-413.

Daëron, M., Guo, W., Eiler, J., Genty, D., Blamart, D., Boch, R., Drysdale, R., Maire, R., Wainer, K., Zanchetta, G. (2011) ${ }^{13} \mathrm{C}^{18} \mathrm{O}$ clumping in speleothems: Observations from natural caves and precipitation experiments. Geochim. Cosmochim. Acta 75, 3303-3317.

Dale, A., John C.M., Mozley P., Smalley P.C., Muggeridge A.H. (2014) Time-capsule concretions: unlocking burial diagenetic processes in the Mancos Shale using carbonate clumped isotopes. Earth and Planetary Science Letters 394, 30-37.

Dennis, K., Schrag, D. (2010) Clumped isotope thermometry of carbonatites as an indicator of diagenetic alteration. Geochimica et Cosmochimica Acta 74, 4110-4122.

Dennis, K.J., Affek, H.P., Passey, B.H., Schrag, D.P., Eiler, J.M. (2011) Defining an absolute reference frame for "clumped"isotope studies of $\mathrm{CO}_{2}$. Geochim. Cosmochim. Acta 75, $7117-7131$.

Derry, L.A. (2010) A burial diagenesis origin for the Ediacaran Shuram-Wonoka carbon isotope anomaly. Earth Planet Sci Lett 294, 152-162. 
Eagle, R.A., Schauble, E.A., Tripati, A.K., Tutken, T., Hulbert, R., Eiler, J.M. (2010) Body temperatures of modern and extinct vertebrates from ${ }^{13} \mathrm{C}-{ }^{18} \mathrm{O}$ bond abundances in bioapatite. Proc. Natl. Acad. Sci. 107, 10377-10382.

Eagle, R. A., T. Tütken, T. S. Martin, A. K. Tripati, H. C. Fricke, M. Connely, R. L. Cifelli, J. M. Eiler (2011), Dinosaur body temperatures determined from isotopic $\left({ }^{13} \mathrm{C}-{ }^{18} \mathrm{O}\right)$ ordering in fossil biominerals. Science 333, 443-445.

Eagle, R., Risi, C., Mitchell, J., Neelin, D., Eiler, J., Seibt, U., Li., G., Tripati, A. (2013) High regional climate sensitivity over continental China inferred from glacial-recent changes in temperature and the hydrologic cycle. Proceedings of the National Academy of Sciences $110,8813-8818$.

Egeberg, P.K., Aagaard, P. (1989) Origin and evolution of formation waters from oil fields on the Norwegian shelf. Applied Geochemistry 4, 131-142.

Ferry, J.M., Passey, B.H., Vasconcelos, C., Eiler, J.M. (2011) Formation of dolomite at 40-80 ${ }^{\circ} \mathrm{C}$ in the Latemar carbonate buildup, Dolomites, Italy, from clumped isotope thermometry. Geology 39, 571-574.

Fike D.A., Grotzinger, J.P., Pratt L.M., Summons, R.E. (2006) Oxidation of the Ediacaran Ocean. Nature 444, 744-747.

Finnegan, S., Bergmann, K., Eiler, J.M., Jones, D.S., Fike, D.A., Eisenman, I., Hughes, N.C., Tripati, A.K., Fischer, W.W. (2011) The magnitude and duration of late Ordovician-early Silurian glaciation. Science 331, 903-906.

Gat, J.R. (1996) Oxygen and hydrogen isotopes in the hydrologic cycle. Annu. Rev. Earth Planet. Sci. 24, 225-262. 
Ghosh, P., Adkins, J., Affek, H., Balta, B., Guo, W., Schauble, E.A., Schrag, D., Eiler, J.M. (2006) ${ }^{13} \mathrm{C}-{ }^{18} \mathrm{O}$ bonds in carbonate minerals: A new kind of paleothermometer. Geochim Cosmochim Acta 70, 1439-1456.

Gross, M.G., Tracey J.I. (1966) Oxygen and Carbon Isotopic Composition of Limestones and Dolomites, Bikini and Eniwetok Atolls. Science 151, 1082-1084.

Grotzinger, J.P., Fike, D.A., Fischer, W.W. (2011) Enigmatic origin of the largest-known carbon isotope excursion in Earth's history. Nat Geosci 4, 285-292.

Guo, W., Mosenfelder, J.L., Goddard III, W.A., Eiler, J.M. (2009) Isotopic fractionations associated with phosphoric acid digestion of carbonate minerals: insights from firstprinciples theoretical modeling and clumped isotope measurements. Geochim Cosmochim Acta 73, 7203-7225.

Halverson, G.P., Hoffman, P.F., Schrag, D.P., Maloof, A.C., Rice, A.H.N. (2005) Toward a Neoproterozoic composite carbon-isotope record. Geol Soc Am Bull 117, 1181-1207. Heaman, L.M., Grotzinger, J.P. (1992) 1.08 Ga diabase sills in the Pahrump Group, California. Implications for development of the Cordilleran miogeocline. Geology 20, 637-640.

Henkes, G.A., Passey, B.H., Grossman, E.L., Shenton, B.J., Perez-Huerta, A., Yancey, T.E. (2014) Temperature limits for the preservation of primary calcite clumped isotope paleothermometers. Geochimica et Cosmochimica Acta 139. 362-382.

Hitchon, B., Friedman, I. (1969) Geochemistry and origin of formation waters in the western Canada sedimentary basin-I. Stable Isotopes of hydrogen and oxygen*. Geochimica et Cosmochimica Acta 33. 1321-1349.

Hoffman, P.F., Kaufman, A.J., Halverson, G.P., Schrag, D.P. (1998) A Neoproterozoic Snowball Earth. Science 281, 1342-1346. 
Huntington, K.W., Eiler, J.M., Affek, H.P., Guo, W., Bonifacie, M., Yeung, L.Y., Thiagarajan, N., Passey, B., Tripati, A., Daeron, M., Came, R. (2009) Methods and limitations of “clumped" $\mathrm{CO}_{2}$ isotope $\left(\Delta_{47}\right)$ analysis by gas-source isotope ratio mass spectrometry. $J$. Mass Spectrom. 44, 1318-1329.

Huntington, K., Wernicke, B., Eiler, J. (2010) The influence of climate change and uplift on Colorado Plateau paleotemperatures from carbonate clumped-isotope thermometry. Tectonics doi: 10.1029/2009TC002449.

Huntington, K.W., Budd, D.A., Wernicke, B.P., Eiler, J.M. (2011) Use of clumped-isotope thermometry to constrain the crystallization temperature of diagenetic calcite. J. Sediment. Res. 81, 656-669.

Jenkins, R. J. F., Cooper, J.A., Compston, W. (2002) Age and biostratigraphy of Early Cambrian tuffs from SE Australia and southern China. J. Geol. Soc. 159, 645-658.

Jiang, G., Kennedy, M.J., Christie-Blick, N., Wu, H., Zhang, S. (2006) Stratigraphy, Sedimentary Structures, and Textures of the Late Neoproterozoic Doushantuo Cap Carbonate in South China. J Sediment Res 76, 978-995.

Jiang, G., Kaufman, A.J., Christie-Blick, N., Zhang, S., Wu, H. (2007) Carbon isotope variability across the Ediacaran Yangtze platform in South China: Implications for a large surface-todeep ocean $\delta^{13} \mathrm{C}$ gradient. Earth Planet Sci Lett 261, 303-320.

Kaufman, A.J., Corsetti, F.A., Varni, M.A. (2007) The effect of rising atmospheric oxygen on carbon and sulfur isotope anomalies in the Neoproterozoic Johnnie Formation, Death Valley, USA. Chem Geol 237, 47-63.

Keating-Bitonti, C., Ivany, L.C., Affek, H.P., Douglas, P., Samson S.D. (2011) Warm, not superhot, temperatures in the early Eocene subtropics. Geology 39, 771-774. 
Kennedy, M.J., Christie-Blick, N., Sohl, L.E. (2001) Are Proterozoic cap carbonates and isotopic excursions a record of gas hydrate destabilization following Earth's coldest intervals? Geology 29, 443-446.

Kim, S.-T., O'Neil, J.R. (1997) Equilibrium and non-equilibrium oxygen isotope effects in synthetic carbonates. Geochim Cosmochim Acta 61, 3461-3475.

Knauth, L.P. (1988) Origin and mixing history of brines, Palo Duro Basin, Texas, U.S.A. Applied Geochemistry 3, 455-474.

Knauth, L.P., Kennedy, M.J. (2009) The late Precambrian greening of the Earth. Nature 460, 728-732.

Knoll, A. (2000) Learning to tell Neoproterozoic time. Precambrian Res 100, 3-20.

Lee, C., Fike, D.A., Love, G.D., Sessions, A.L., Grotzinger, J.P., Summons, R.E., Fischer, W.W. (2013) Carbon isotopes and lipid biomarkers from organic-rich facies of the Shuram Formation, Sultanate of Oman. Geobiology 11, 406-419.

Le Guerroue, E., Allen, P., Cozzi, J., Etienne, J., Fanning, M. (2006) 50 million year duration negative carbon isotope excursion in the Ediacaran ocean. Terra Nova 18, 147-153.

Loyd, S., Corsetti, F., Eiler, J., Tripati, A. (2012a) Determining the diagenetic conditions of concretion formation: Assessing temperatures and pore-waters using clumped isotopes. Journal of Sedimentary Research 82, 1006-1016.

Loyd, S.J., Marenco, P.M., Hagadorn, J.W., Lyons, T.W., Kaufman, A.J., Sour-Tovar, F., Corsetti, F.A. (2012b) Sustained low marine sulfate concentrations from the Neoproterozoic to the Cambrian: Insights from carbonates of northwestern Mexico and eastern California. Earth Planet Sci Lett 339-340, 79-94. 
Loyd, S.J., Dickson, J.A.D., Scholle, P.A., Tripati, A.K. (2013a) Extensive, uplift-related and non-fault-controlled spar precipitation in the Permian Capitan Formation. Sedimentary Geology 298, 17-27.

Loyd, S.J., Marenco, P.M., Hagadorn, J.W., Lyons, T.W., Kaufman, A.J., Sour-Tovar, F., Corsetti, F.A. (2013b) Local $\delta^{34} \mathrm{~S}$ variability in $\square 580$ Ma carbonates of northwestern Mexico and the Neoproterozoic marine sulfate reservoir. Precambrian Res 224, 551-569.

Loyd, S.J., Dickson, J.A.D., Boles, J.R., Tripati, A.K. (2014) Clumped isotope constraints on cement paragenesis in septarian concretions. Journal of Sedimentary Research 84, 11701184.

Moldovanyi, E.P., Walter, L.M., Land, L.S. (1993) Strontium, boron, oxygen, and hydrogen isotope geochemistry of brines from basal strata of the Gulf Coast sedimentary basin, USA. Geochimica et Cosmochimica Acta 57, 2083-2099.

Pauwels, H., Fouillac, C., Fouillac, A. (1993) Chemistry and isotopes of deep geothermal saline fluids in the Upper Rhine Graben: Origin of compounds and water-rock interactions. Geochimica et Cosmochimica Acta 57. 2737-2749.

Passey, B.H., Levin, N.E., Cerling, T.E., Brown, F.H., Eiler, J.M. (2010) High-temperature environments of human evolution in East Africa based on bond ordering in paleosol carbonates. Proc. Natl. Acad. Sci. 107, 11245-11249.

Passey, B.H., Henkes, G.A. (2012) Carbonate clumped isotope bond reordering and geospeedometry. Earth Planet. Sci. Lett. 351-352, 223-236.

Pruss, S.B., Corsetti, F.A., Fischer, W.W. (2007) Seafloor-precipitated carbonate fans in the Neoproterozoic Rainstorm Member, Johnnie Formation, Death Valley Region, USA. Sedimentary Geology 207, 34-40. 
Rothman, D.H., Hayes, J.M., Summons, R.E. (2003) Dynamics of the Neoproterozoic carbon cycle. Proc Natl Acad Sci 100, 8124-8129.

Rozanski, K., Araguás-Araguás, L., Gonfiantini, R. (1993) Isotopic patterns in modern global precipitation, in Continental Isotope Indicators of Climate, American Geophysical Union Monograph.

Saenger, C., Affek, H.P., Felis, T., Thiagarajan, N., Lough, J.M., Holcomb, M. (2012) Carbonate clumped isotope variability in shallow water corals: Temperature dependence and growthrelated vital effects. Geochim. Cosmochim. Acta 99, 224-242.

Sandberg, P.A. (1975) New interpretations of Great Salt Lake ooids and of ancient non-skeletal carbonate mineralogy. Sedimentology 22, 497-537.

Sour-Tovar, F., Hagadorn, J.W., Huitrón-Rubio, T. (2007) Ediacaran and Cambrian Index Fossils from Sonora, Mexico. Palaeontology 50, 169-175.

Stewart, J.H. (1966) Correlation of Lower Cambrian and some Precambrian strata in the southern Great Basin, California and Nevada: Geologic guide to the Death Valley area, California. Geological Survey Professional Paper (Sacramento, CA), 1-7.

Stewart, J.H. (1970) Upper Precambrian and lower Cambrian strata in the southern Great Basin, California and Nevada, Geological Survey Professional Paper 620, 206 p.

Stewart, J.H., McMenamin, M.A., Morales-Ramírez, J.M. (1984) Upper Proterozoic and Cambrian rocks in the Caborca region, Sonora, Mexico: Physical stratigraphy, biostratigraphy, paleocurrent studies, and regional relations. Geological Survey Professional Paper 1309, $36 \mathrm{p}$.

Swanson, E.M., Wernicke, B.P., Eiler, J.M., Losh, S. (2012) Temperatures and fluids on faults based on carbonate clumped-isotope thermometry. American Journal of Science 312, 1-21. 
Swart, P.K., Kennedy, M.J. (2012) Does the global stratigraphic reproducibility of $\delta^{13} \mathrm{C}$ in Neoproterozoic carbonates require a marine origin? A Pliocene-Pleistocene comparison. Geology 40, 87-90.

Tang, J., Dietzel, M., Fernandez, A., Tripati, A., Rosenheim, B.E. (2014) Evaluation of kinetic effects on clumped isotope fractionation $\left(\Delta_{47}\right)$ during inorganic calcite precipitation. Geochimica et Cosmochimica Acta 134, 120-136.

Tripati, A., Eagle, R., Thiagarajan, N., Gagnon, A., Bauch, H., Halloran, P., Eiler, J. (2010) ${ }^{13}$ C${ }^{18} \mathrm{O}$ isotope signatures and "clumped isotope" thermometry in foraminifera and coccoliths. Geochimica et Cosmochimica Acta 74, 5697-5717.

Tripati, A., Sahany, S., Pittman, D., Eagle, R., Neelin, D., Mitchell, J., Beaufort, L., (2014) Modern and glacial tropical snowlines controlled by sea surface temperature and atmospheric mixing. Nature Geoscience 7, 205-209.

Vasconcelos, C., McKenzie, J.A., Warthmann, R., Bernasconi, S.M. (2005) Calibration of the $\delta^{18} \mathrm{O}$ paleothermometer for dolomite precipitated in microbial cultures and natural environments. Geology 33, 317-320.

Wilson, T.P., Long, D.T. (1993) Geochemistry and isotope chemistry of Michigan Basin Brines: Devonian formations. Applied Geochemistry 8, 81-100.

Yurtsever, Y., Gat, J.R. (1981) Atmospheric waters, in J.R. Gat, R. Gonfiantini, eds., Stable Isotope Hydrology. IAEA Tech. Rep. Ser. 210, 103-142.

Zaarur, S., Affek, H.P., Brandon, M.T. (2013) A revised calibration of the clumped isotope thermometer. Earth and Planetary Science Letters 382, 47-57.

Zhou, C., Tucker, R.D., Xiao, S., Peng, Z., Yuan, X., Chen, Z. (2004) New constraints on the ages of Neoproterozoic glaciations in south China. Geology 32, 437-440. 
Fig. 1: Stratigraphic expression of the Wonoka-Shuram Anomaly. Anomalies of different sites (formations in parentheses) are scaled based on the stratigraphic thickness of the excursion (as in Figure 3 of Grotzinger et al. 2011), and include additional data (Corsetti and Kaufman, 2003; Loyd et al., 2012b). The south China data (from Jiang et al., 2007) originate from the same samples analyzed here. These expressions are not internally manipulated, but rather simply pinned based on the anomaly inception and its return to values near $0 \%$. Notice the asymmetry expressed at all sites.

Fig. 2. Cross plot of $\delta^{13} \mathrm{C}_{\text {carb }}$ and $\delta^{18} \mathrm{O}_{\text {carb }}$ data for a number of Neoproterozoic sequences that exhibit the Wonoka-Shuram Anomaly. Previously published data in grey (Derry, 2010), colored data from this study.

Fig. 3: Stratigraphy, carbon isotope chemostratigraphy and associated carbonate precipitation temperatures of the successions and units explored in this study. Notice the lack of a common systematic variation in stratigraphic height and temperature. WSA = Wonoka-Shuram Anomaly. Carbon isotopes and stratigraphy as previously reported for Sonora (Loyd et al., 2012b), Death Valley (Corsetti and Kaufman, 2003) and South China (Jiang et al., 2007). Black symbols correspond to new data presented here. pC-C = Precambrian-Cambrian boundary. Average long-term standard reproducibility provided as $+/-1$ s.e. for each section. 
Fig. 4. Temperature and $\delta^{18} \mathrm{O}_{\mathrm{w}}$ data from modern formation fluids compared to those reconstructed from clumped isotope and $\delta^{18} \mathrm{O}_{\text {carb }}$ data of the Neoproterozoic carbonates examined here. Notice the similarity in trends. Average long-term standard reproducibility provided as $+/-1$ s.e..

Fig. 5. Cross plots of clumped isotope temperature and oxygen isotope data $\left(\delta^{18} \mathrm{O}_{\text {carb }} \square \square \square \delta^{18} \mathrm{O}_{\mathrm{w}}\right.$ ) from Sonora Mexico. Left plots show temperature and $\delta^{18} \mathrm{O}_{\text {carb }}$ relationships and right plots show temperature and $\delta^{18} \mathrm{O}_{\mathrm{w}}$ relationships. The plots also include evolutionary trajectories for different water rock ratios (W/R) as they pertain to mineralogy (calcite or dolomite) and initial fluid $\left(\delta_{\mathrm{f}}\right)$ and carbonate mineral $\left(\delta_{\mathrm{c}}\right)$ isotopic compositions. The top plots trajectories correspond to modern marine values of $\delta_{\mathrm{c}}=31 \%$ o VSMOW (or $\sim 0 \%$ VPDB) and $\delta_{\mathrm{f}}=0 \%$ VSMOW. The bottom plots trajectories correspond to carbonate minerals precipitated in equilibrium with seawater $\left(\delta_{\mathrm{c}}=31 \%\right.$ o VSMOW) recrystallizing in the presence of an isotopically depleted fluid with $\delta_{\mathrm{f}}=-10 \%$ o VSMOW. Notice how the bottom plots better account for the complete data set. Both temperature vs. $\delta^{18} \mathrm{O}_{\text {carb }}$ and temperature vs. $\delta^{18} \mathrm{O}_{\mathrm{w}}$ exhibit statistically significant positive correlation at the $95 \%$ confidence level. The details of the W/R models are provided in Supplementary Information. Average long-term standard reproducibility provided as +/1 s.e..

Fig. 6. Cross plots of clumped isotope temperature and oxygen isotope data $\left(\delta^{18} \mathrm{O}_{\text {carb }} \square \square \square \delta^{18} \mathrm{O}_{\mathrm{w}}\right.$ ) from Death Valley U.S.A., similar to those of Fig. 5. Here, the top 
plots trajectories correspond to modern seawater values of $\delta_{\mathrm{c}}=31 \%$ VSMOW (or $\sim 0 \%$ o VPDB) and $\delta_{\mathrm{f}}=0 \%$ VSMOW. The bottom plots trajectories correspond to carbonate minerals precipitated in equilibrium with seawater $\left(\delta_{\mathrm{c}}=31 \%\right.$ VSMOW $)$ recrystallizing in the presence of an isotopically depleted fluid with $\delta_{\mathrm{f}}=-15 \%$ VSMOW. As in Fig. 5, the bottom plots better account for the complete data set. Both temperature vs. $\delta^{18} \mathrm{O}_{\text {carb }}$ and temperature vs. $\delta^{18} \mathrm{O}_{\mathrm{w}}$ exhibit statistically significant positive correlation at the $95 \%$ confidence level. The details of the W/R models are provided in Supplementary Information. Average long-term standard reproducibility provided as $+/-1$ s.e..

Fig. 7. Cross plots of clumped isotope temperature and oxygen isotope data ( $\delta^{18} \mathrm{O}_{\text {carb }} \square \square \square \delta^{18} \mathrm{O}_{\mathrm{w}}$ ) from South China, similar to those of Figs. 5 and 6 . The top plots trajectories correspond to modern seawater values of $\delta_{\mathrm{c}}=31 \%$ VSMOW (or $\sim 0 \%$ o VPDB) and $\delta_{\mathrm{f}}=0 \%$ VSMOW. The bottom plots trajectories correspond to carbonate minerals precipitated in equilibrium with seawater $\left(\delta_{\mathrm{c}}=31 \%\right.$ VSMOW $)$ recrystallizing in the presence of an isotopically depleted fluid with $\delta_{\mathrm{f}}=-10 \%$ VSMOW. As in Figs. 5 and 6 , the bottom plots better account for the complete data set. Both temperature vs. $\delta^{18} \mathrm{O}_{\text {carb }}$ and temperature vs. $\delta^{18} \mathrm{O}_{\mathrm{w}}$ exhibit statistically significant positive correlation at the $95 \%$ confidence level. The details of the W/R models are provided in Supplementary Information. Average long-term standard reproducibility provided as $+/-1$ s.e..

Fig. 8. Cross plots of reconstructed fluid oxygen isotope compositions $\left(\delta^{18} \mathrm{O}_{\mathrm{w}}\right)$ and carbonate carbon isotope compositions $\left(\delta^{13} \mathrm{C}_{\text {carb }}\right)$. A) Sonora Mexico, B) Death Valley, C) 
South China. Data largely exhibit poor correlation. Symbols same as in Figs. 5-7. Average long-term standard reproducibility provided as $+/-1$ s.e..

Fig. 9. Oxygen isotope ranges of modern and reconstructed Neoproterozoic fluids. Notice that the reconstructed $\delta^{18} \mathrm{O}_{\mathrm{w}}$ values overlap with modern formation fluids (also see Fig. 4). Initial fluid $\delta^{18} \mathrm{O}$ values (as determined using the water-rock model) more closely resemble non-equatorial meteoric waters, suggesting recrystallization/reequilibration far from the original depositional environment. Modern isotope compositions after Yurtsever and Gat, 1981; Barry and Chorley, 1987; Rozanski et al., 1993; Gat, 1996; Clark and Fritz, 1997.

Table 1. Geochemical Data. Bolded samples were analyzed in duplicate, each individual sample is the average of eight data acquisitions. Standard errors (s.e.) correspond to the long-term reproducibility of standards. Standard deviations (s.d.) correspond to duplicate analyses where applicable. 
Sample ID $\begin{gathered}\text { Strat. Height } \\ \text { ( } \mathrm{m} \text {-above base) }\end{gathered}$

\begin{tabular}{|c|c|c|c|c|}
\hline \multicolumn{5}{|l|}{$\begin{array}{l}\text { Sonora } \\
\text { So }\end{array}$} \\
\hline $\begin{array}{l}\text { CREA } 31.5 \\
\text { CREA } 60\end{array}$ & $\begin{array}{l}60 \\
88.5\end{array}$ & $\begin{array}{l}\mathrm{NE} \\
\mathrm{NE}\end{array}$ & $\begin{array}{l}\text { dolomite } \\
\text { dolomite }\end{array}$ & $\begin{array}{l}\text { lower dolomite } \\
\text { lower dolomite }\end{array}$ \\
\hline RC 119 & 147.5 & $\mathrm{NE}$ & dolomite & lower dolomite \\
\hline CRC 135 & 163.5 & $\mathrm{NE}$ & dolomite & lower dolomite \\
\hline CRC 160 & $\begin{array}{l}188.5 \\
200\end{array}$ & ${ }_{N E}^{N E}$ & dolomite & lower dolomite \\
\hline $\begin{array}{l}\mathrm{CRC} 180.5 \\
\mathrm{CRCm} 333\end{array}$ & $\begin{array}{l}209 \\
361.5\end{array}$ & $\begin{array}{c}\text { NE } \\
\text { E }\end{array}$ & $\begin{array}{l}\text { dolomite } \\
\text { dolomite }\end{array}$ & $\begin{array}{l}\text { lower dolomite } \\
\text { lower dolomite }\end{array}$ \\
\hline CRCm 333.45 & 361.95 & E & dolomite & lower dolomite \\
\hline CRCm 333.9 & $\begin{array}{c}362.4 \\
362.85\end{array}$ & E & dolomite & lower dolomite \\
\hline $\begin{array}{l}\text { CRCm 334.35 } \\
\text { CRCm 334.65 }\end{array}$ & $\begin{array}{l}\mathbf{3 6 2 2 . 8 5} \\
363.15\end{array}$ & $\begin{array}{l}\mathrm{E} \\
\mathrm{E}\end{array}$ & 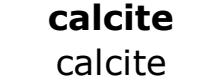 & $\begin{array}{l}\text { lower calcite } \\
\text { lower calcite }\end{array}$ \\
\hline CRCm 335.55 & 364.05 & $\mathrm{E}$ & calcite & lower calcite \\
\hline CRCm 335.7 & 364.2 & $E$ & calcite & lower calcite \\
\hline $\begin{array}{l}\text { CRG } 0 \\
\text { CRP } 22\end{array}$ & $\begin{array}{l}500.5 \\
672.5\end{array}$ & ${ }_{N E}^{N E}$ & dolomite & upper dolomite \\
\hline $\begin{array}{l}\text { CRPa 22 } \\
\text { CRPa 40 }\end{array}$ & $\begin{array}{l}672.5 \\
690.5\end{array}$ & $\begin{array}{l}\mathrm{NE} \\
\mathrm{NE}\end{array}$ & $\begin{array}{l}\text { dolomite } \\
\text { dolomite }\end{array}$ & $\begin{array}{l}\text { upper dolomite } \\
\text { upper dolomite }\end{array}$ \\
\hline $\begin{array}{l}\text { CRPA } 80 \\
\text { CRP }\end{array}$ & 730.5 & & $\begin{array}{l}\text { dolomite } \\
\text { dolomite }\end{array}$ & $\begin{array}{l}\text { upper dolomite } \\
\text { upper dolomite }\end{array}$ \\
\hline 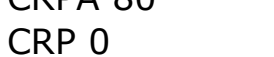 & 788.5 & & $\begin{array}{l}\text { aolomice } \\
\text { dolomite }\end{array}$ & $\begin{array}{l}\text { Upper aolomite } \\
\text { upper dolomite }\end{array}$ \\
\hline CRP 41 & & & dolomite & upper dolomite \\
\hline CRP 120.5 & 909 & & dolomite & upper dolomite \\
\hline CRP 160 & 948.5 & $\mathrm{NE}$ & dolomite & upper dolomite \\
\hline CRP 180 & 968.5 & $\mathrm{NE}$ & dolomite & upper dolomite \\
\hline CRP 235 & 1023.5 & NE & dolomite & upper dolomite \\
\hline $\begin{array}{l}\text { CRTa } 84 \\
\text { CDI } 82\end{array}$ & $\begin{array}{l}1143.5 \\
12815\end{array}$ & $\begin{array}{l}\text { NE } \\
\text { NE }\end{array}$ & dolomite & upper dolomite \\
\hline $\begin{array}{l}\text { CRLC } 83 \\
\text { CRLC } 103\end{array}$ & $\begin{array}{l}181.5 \\
1301.5\end{array}$ & $\begin{array}{l}\mathrm{Ne} \\
\mathrm{NE}\end{array}$ & $\begin{array}{l}\text { aolomice } \\
\text { dolomite }\end{array}$ & $\begin{array}{l}\text { upper dolomite } \\
\text { yneer dolomite }\end{array}$ \\
\hline CLLC 142 & $\begin{array}{l}1301.5 \\
1340.5\end{array}$ & & dolomite & $\begin{array}{l}\text { upper dolomite } \\
\text { upper }\end{array}$ \\
\hline CRPB 398 & 1786.5 & $\mathrm{~N}$ & calcite & upper calcite \\
\hline & & & calcite & upper calcite \\
\hline & & & calcite & upper calcite \\
\hline & 5 & & calcite & upper ca \\
\hline $\begin{array}{l}0 \\
110\end{array}$ & $\begin{array}{l}2336.5 \\
2346.5\end{array}$ & $\begin{array}{l}\mathrm{NE} \\
\mathrm{NE}\end{array}$ & $\begin{array}{l}\text { calcite } \\
\text { calcite }\end{array}$ & $\begin{array}{l}\text { upper ralcite } \\
\text { upper calcite }\end{array}$ \\
\hline
\end{tabular}

$\begin{array}{lccc}\text { Death Valley } & & & \\ \text { LND-5-7 } & -198 & \text { NE } & \text { dolomite } \\ \text { LND-5-200 } & -5 & \text { NE } & \text { dolomite } \\ \text { C91-30 } & 205 & \text { NE } & \text { dolomite } \\ \text { C91-31 } & 255 & \text { NE } & \text { dolomite } \\ \text { C91-34 } & 410 & \text { NE } & \text { dolomite } \\ \text { C91-35 } & 435 & \text { NE } & \text { dolomite } \\ \text { JO-B } & 457 & \text { E } & \text { dolomite } \\ \text { C91-36 } & 458 & \text { E } & \text { dolomite } \\ \text { RS2-B } & 489.5 & \text { E } & \text { dolomite } \\ \text { RS2-Fan } & 490 & \text { E } & \text { dolomite } \\ \text { C91-37 } & 493 & \text { E } & \text { dolmite } \\ \text { C91-38 } & 504 & \text { E } & \text { dolomite }\end{array}$

\section{South China}

s.

JLW-S-4-

$\mathrm{J} L \mathrm{~W}-\mathrm{S}-\mathrm{S}-3-4$
$\mathrm{JL}-\mathrm{S}-3-1$

$\mathrm{JLW}-\mathrm{S}-3-2$
$\mathrm{JLW}-\mathrm{S}-3-3$
$\mathrm{JLW}-\mathrm{S}-3-4$

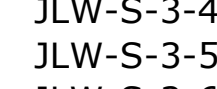

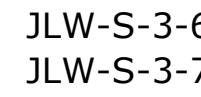

JLW-S-2-2

$\mathrm{JLW}-\mathrm{S}-2-4$
$\mathrm{JLW}-\mathrm{S}-1-1$
$\mathrm{JLW}-\mathrm{S}-1-2$

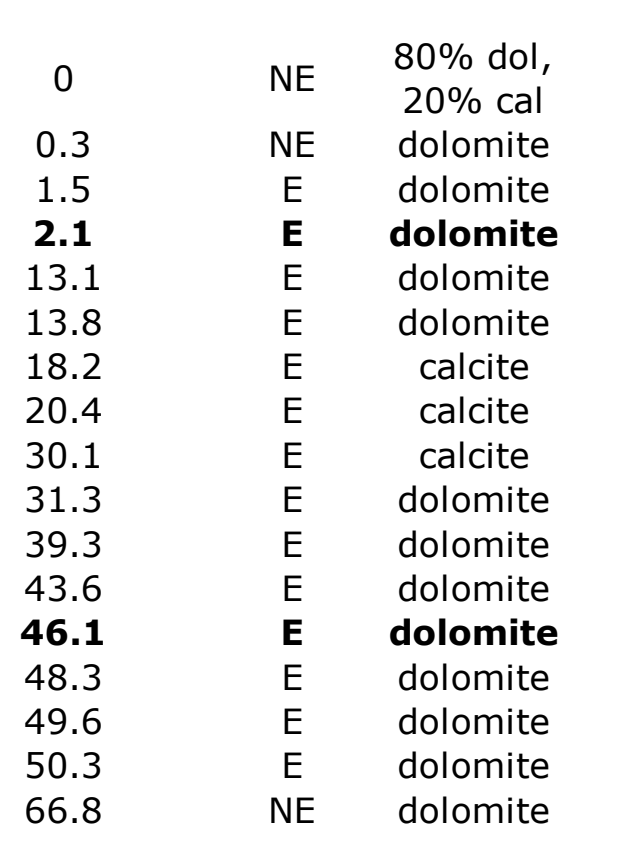

$\begin{array}{lll}47 & 1 \text { s.e. } & 1 \text { s.d. } \\ (\%) & (\% 0) & (\% o)\end{array}$

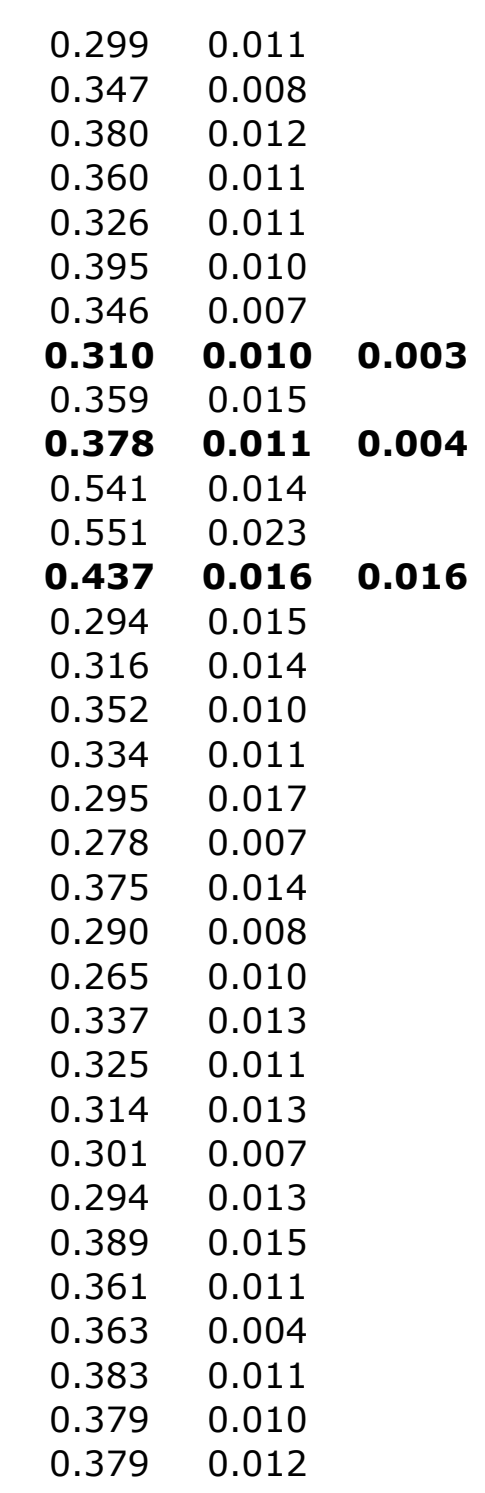

$\begin{array}{ll}0.380 & 0.011 \\ 0.355 & 0.013 \\ 0.393 & 0.011 \\ 0.357 & 0.014 \\ 0.393 & 0.032 \\ 0.369 & 0.019 \\ 0.363 & 0.010 \\ 0.399 & 0.010 \\ 0.571 & 0.035 \\ 0.444 & 0.032 \\ 0.387 & 0.019 \\ 0.393 & 0.031\end{array}$

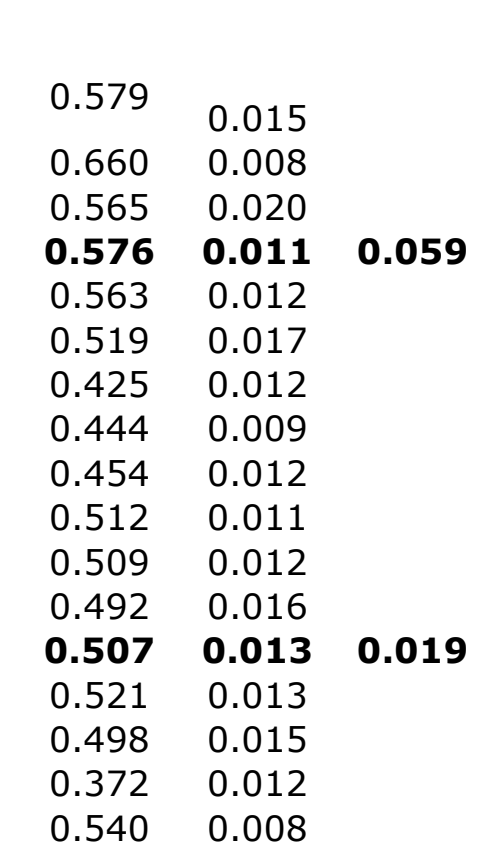

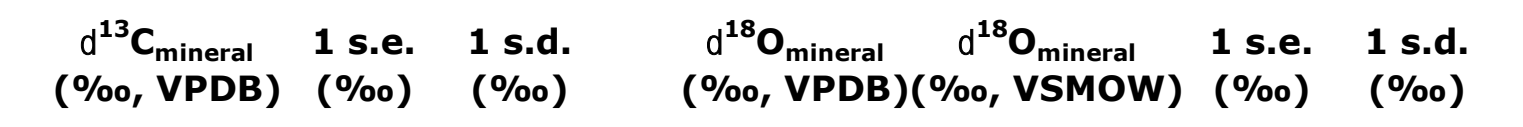
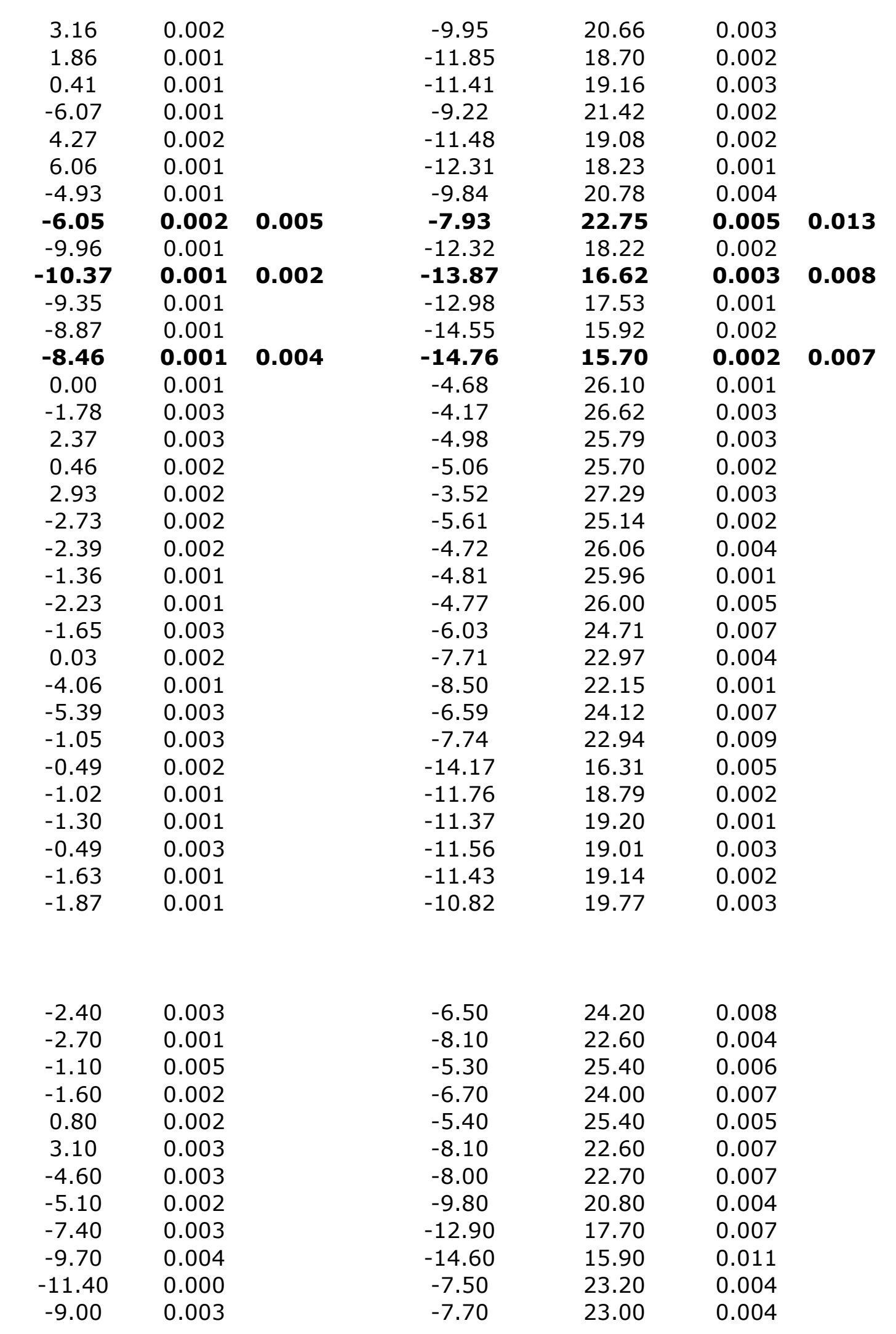

$\begin{array}{lll}-6.50 & 24.20 & 0.008 \\ -8.10 & 22.60 & 0.004 \\ -5.30 & 25.40 & 0.006 \\ -6.70 & 24.00 & 0.007 \\ -5.40 & 25.40 & 0.005 \\ -8.10 & 22.60 & 0.007 \\ -8.00 & 22.70 & 0.007 \\ -9.80 & 20.80 & 0.004 \\ -12.90 & 17.70 & 0.007 \\ -14.60 & 15.90 & 0.011 \\ -7.50 & 23.20 & 0.004 \\ -7.70 & 23.00 & 0.004\end{array}$

\begin{tabular}{|c|c|c|c|}
\hline-2.20 & 0.003 & & -6.60 \\
\hline-1.70 & 0.002 & & 0.30 \\
\hline 1.80 & 0.002 & & -3.10 \\
\hline $\begin{array}{c}\mathbf{0 . 4 5} \\
-666\end{array}$ & $\begin{array}{l}0.003 \\
0.002\end{array}$ & 0.008 & $\begin{array}{l}-1.55 \\
-5.20\end{array}$ \\
\hline-6.50 & 0.004 & & $\begin{array}{l}-5.20 \\
-6.00\end{array}$ \\
\hline-8.50 & 0.002 & & -7.70 \\
\hline-8.20 & 0.002 & & -7.90 \\
\hline-8.50 & 0.002 & & -10.80 \\
\hline $\begin{array}{r}-9.00 \\
0.00\end{array}$ & 0.003 & & $\begin{array}{l}-7.10 \\
\end{array}$ \\
\hline $\begin{array}{l}-8.90 \\
-6.30\end{array}$ & $\begin{array}{l}0.004 \\
0.000\end{array}$ & & $\begin{array}{l}-6.50 \\
-4.20\end{array}$ \\
\hline $\begin{array}{l}-0.30 \\
-2.80\end{array}$ & 0.003 & 0.005 & $\begin{array}{l}-5.20 \\
-5.20\end{array}$ \\
\hline $\begin{array}{l}-2.00 \\
-2.00\end{array}$ & 0.003 & & -4.80 \\
\hline-0.70 & 0.001 & & -4.80 \\
\hline 0.30 & 0.002 & & -4.70 \\
\hline 4.20 & 0.002 & & -4.10 \\
\hline
\end{tabular}

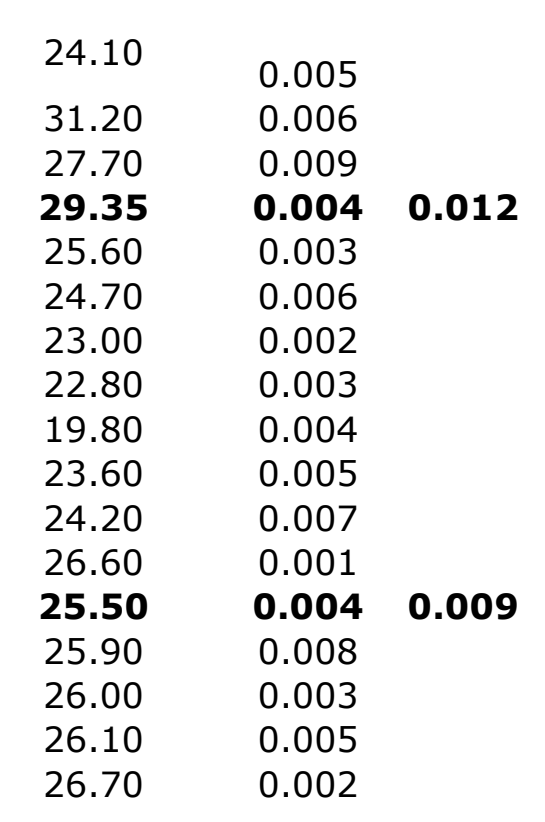

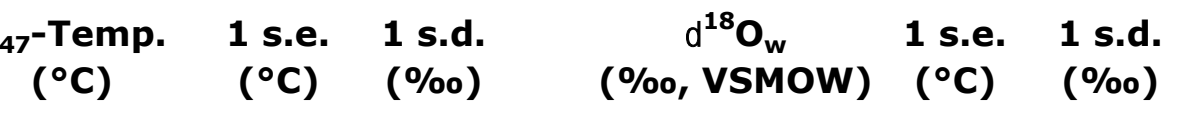
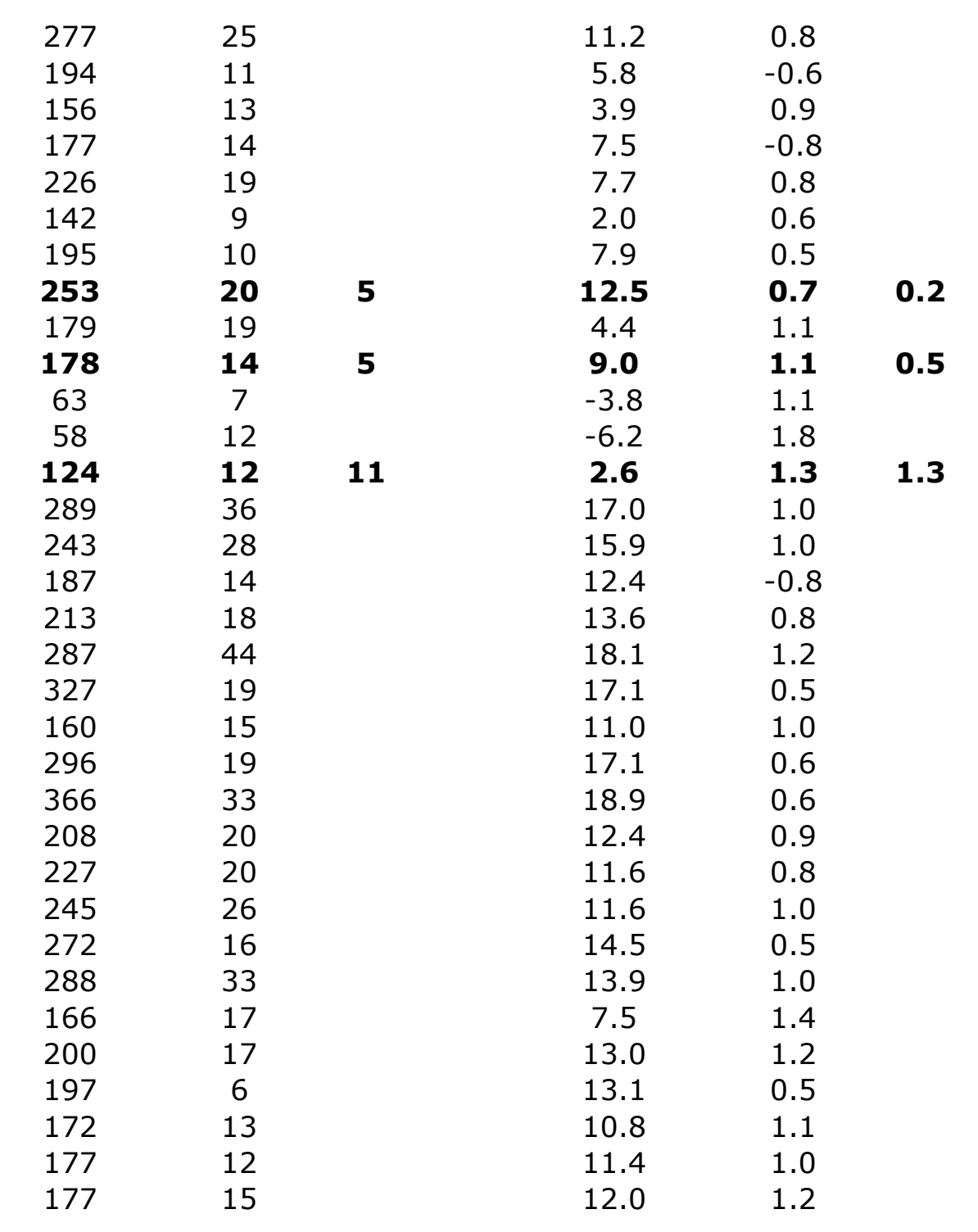

$\begin{array}{lc}156 & 10 \\ 183 & 15 \\ 144 & 9 \\ 181 & 16 \\ 144 & 25 \\ 167 & 19 \\ 174 & 11 \\ 139 & 8 \\ 40 & 10 \\ 107 & 19 \\ 149 & 16 \\ 144 & 24\end{array}$

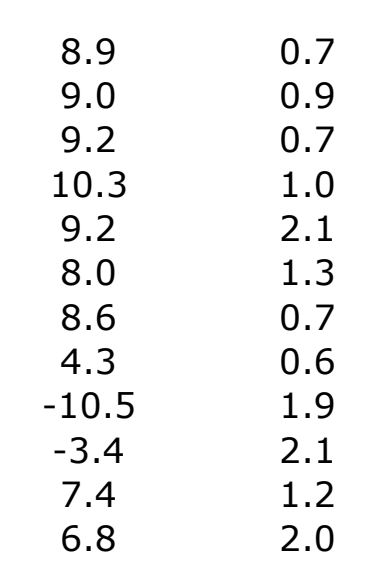

38
34
42
$\mathbf{4 2}$
43
64
133
119
112
68
69
78
70
63
75
164
53

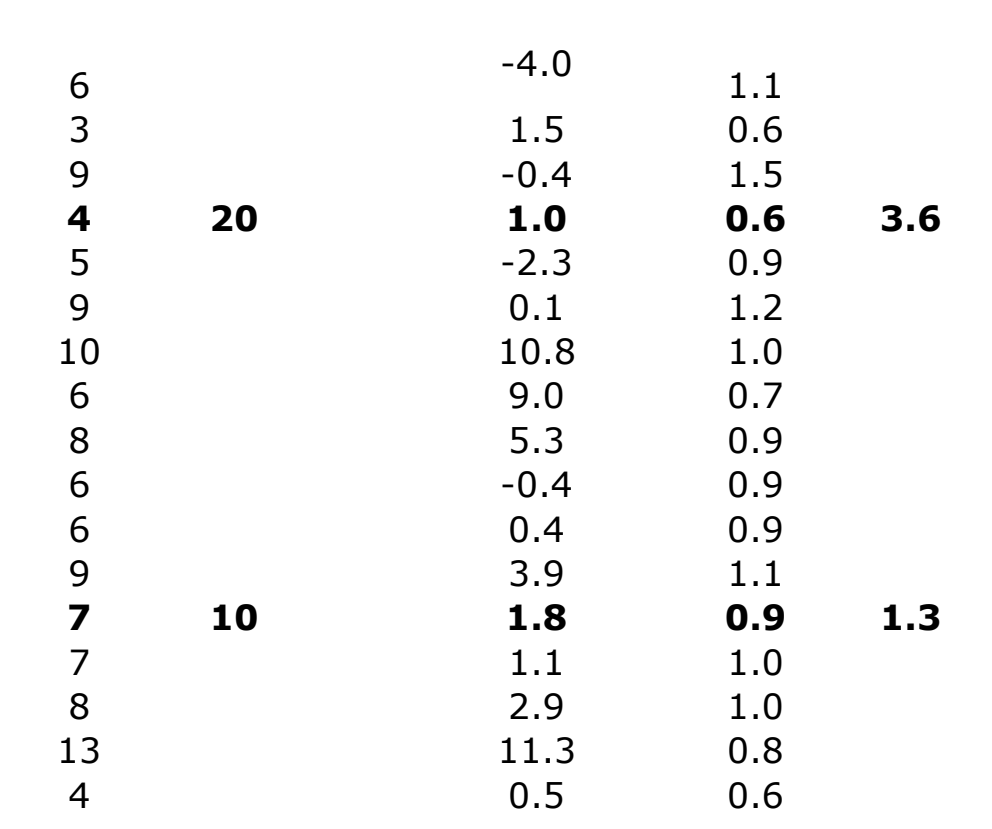

**subgroup refers to the statistical analyses groupings referred to in Supplementary Table 1 (Sonora only) 
Figure 1

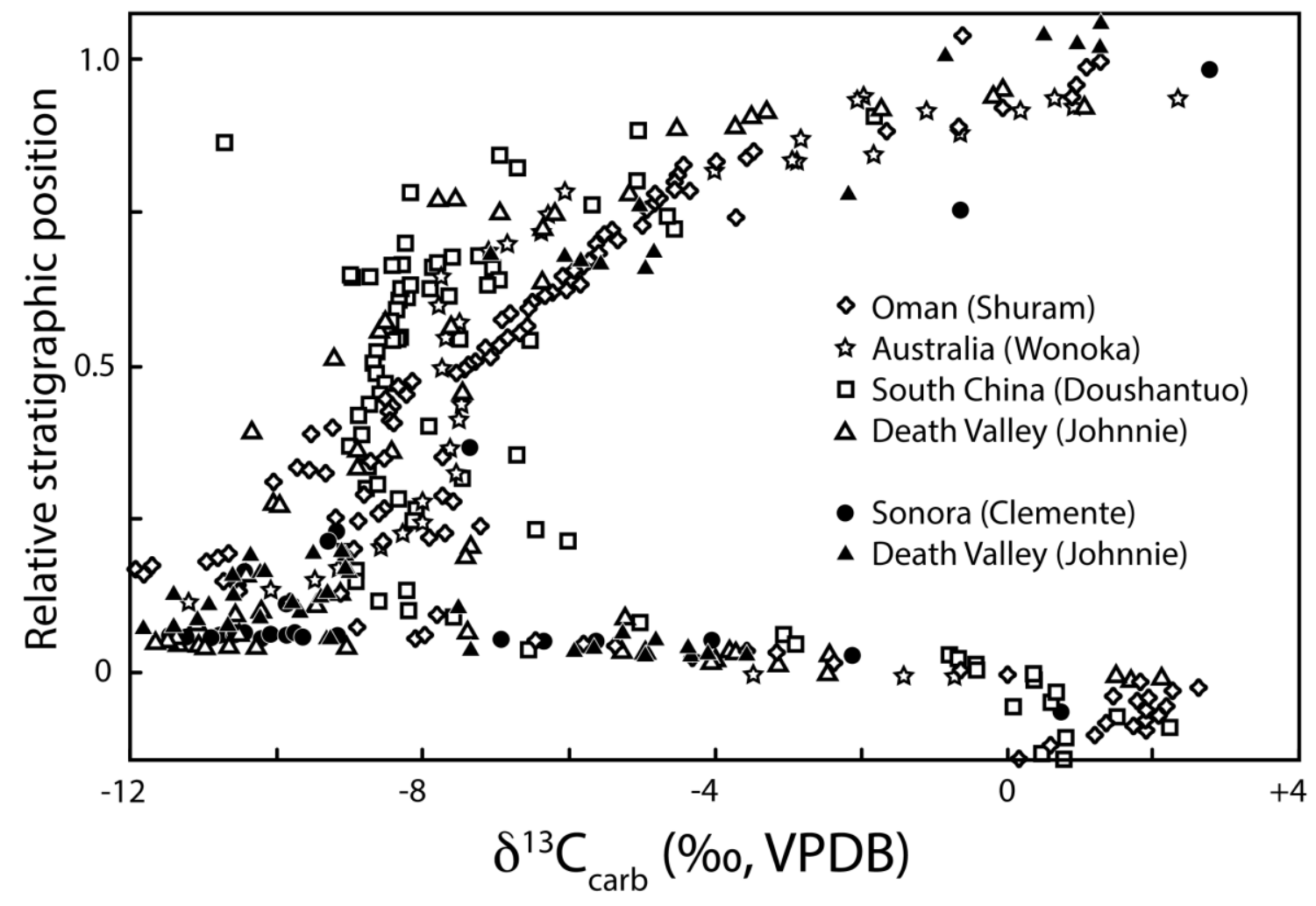


Figure 2

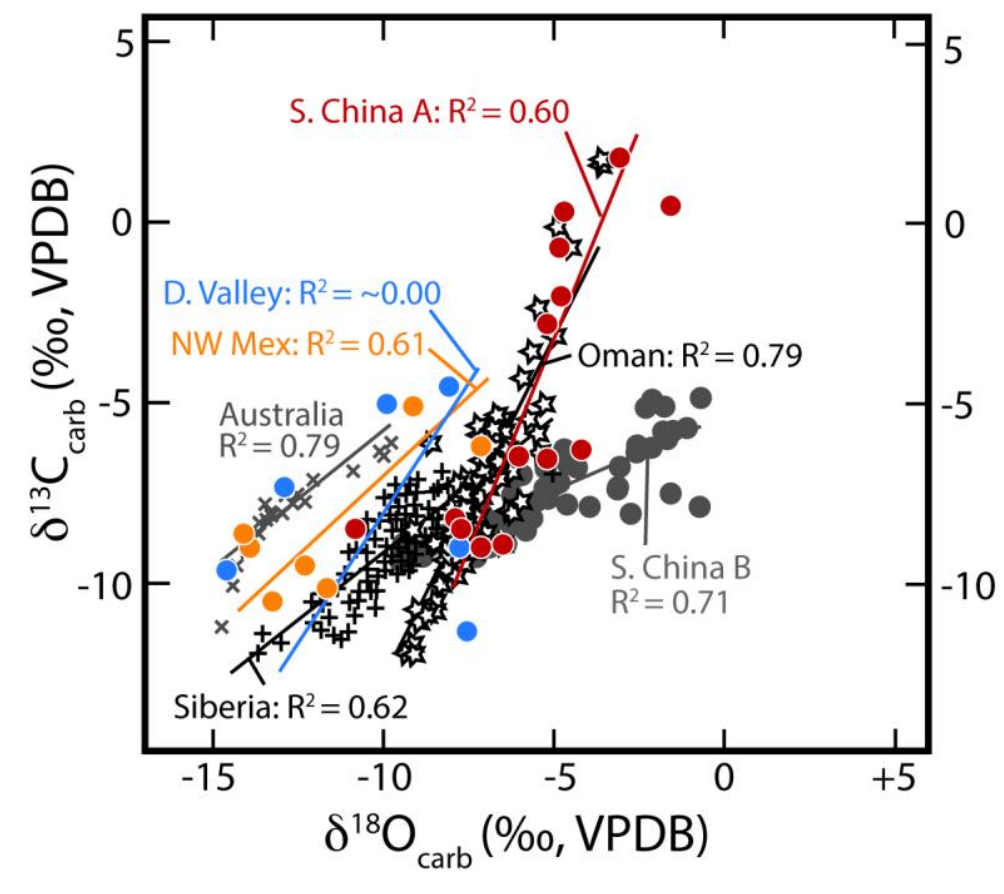


Figure 3
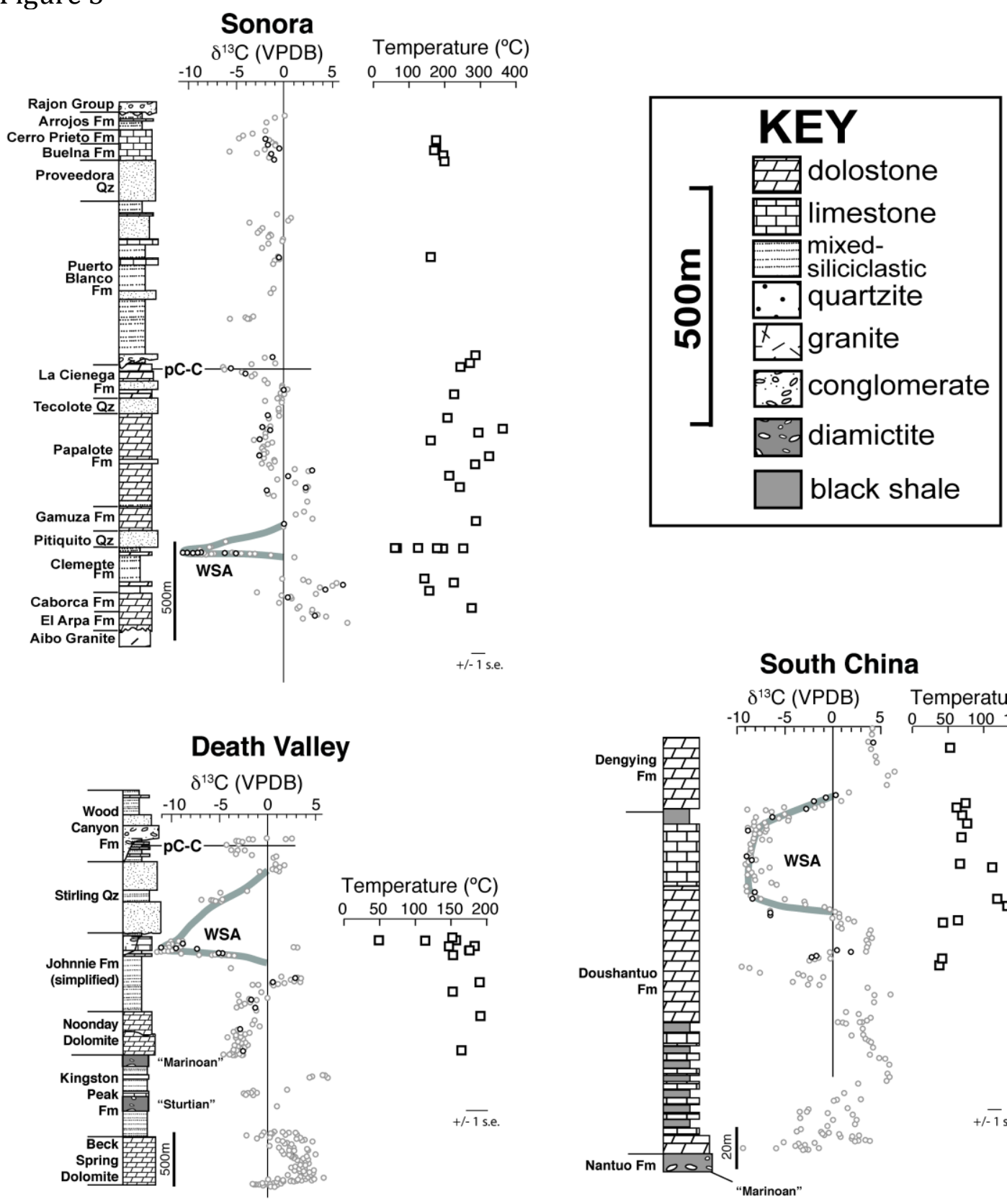

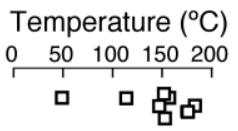

ㅁ

ㅁ

ㅁ

$+\overline{-1 \text { s.e. }}$

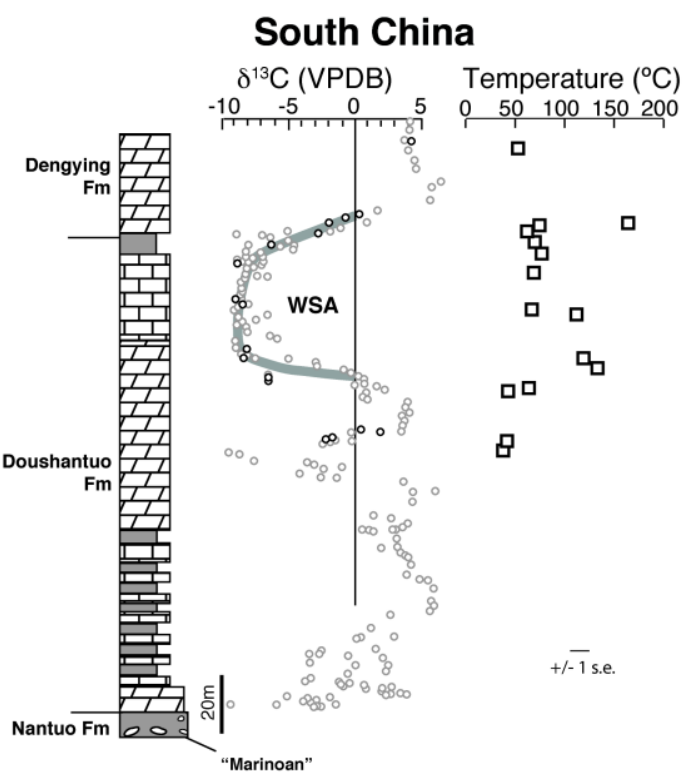


Figure 4

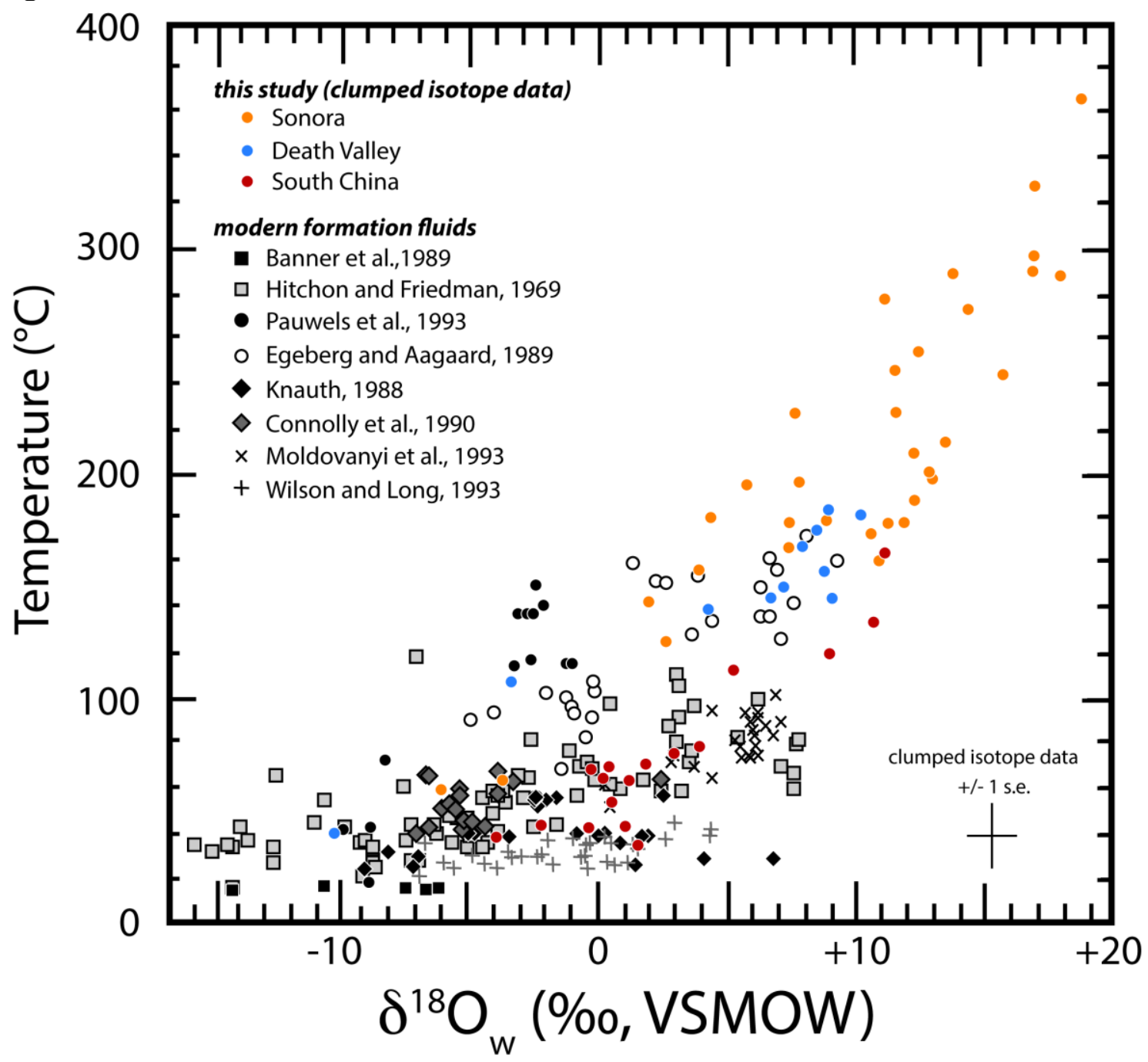


Figure 5

Figure 5

\section{Sonora}
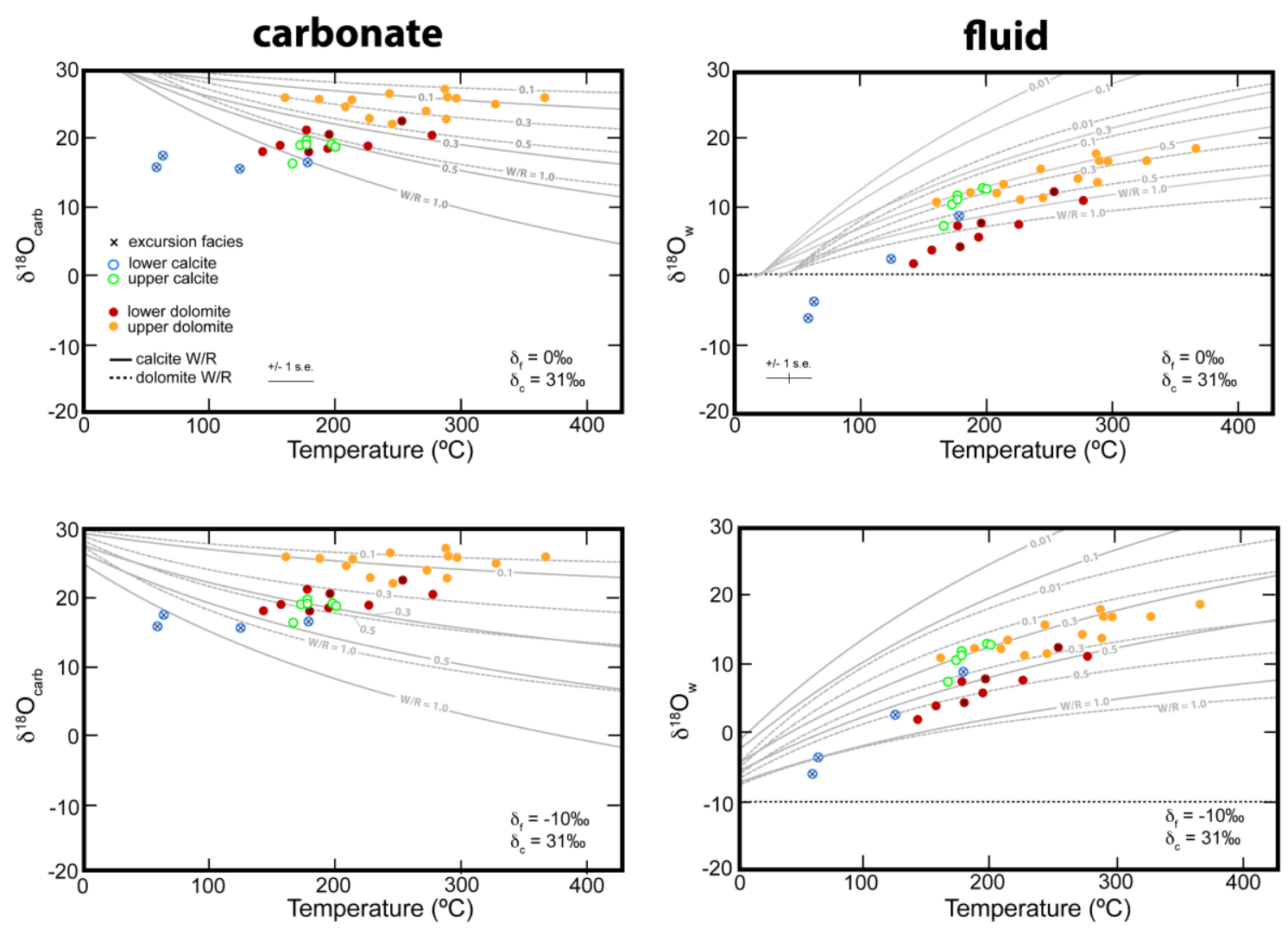
Figure 6

\section{Death Valley}
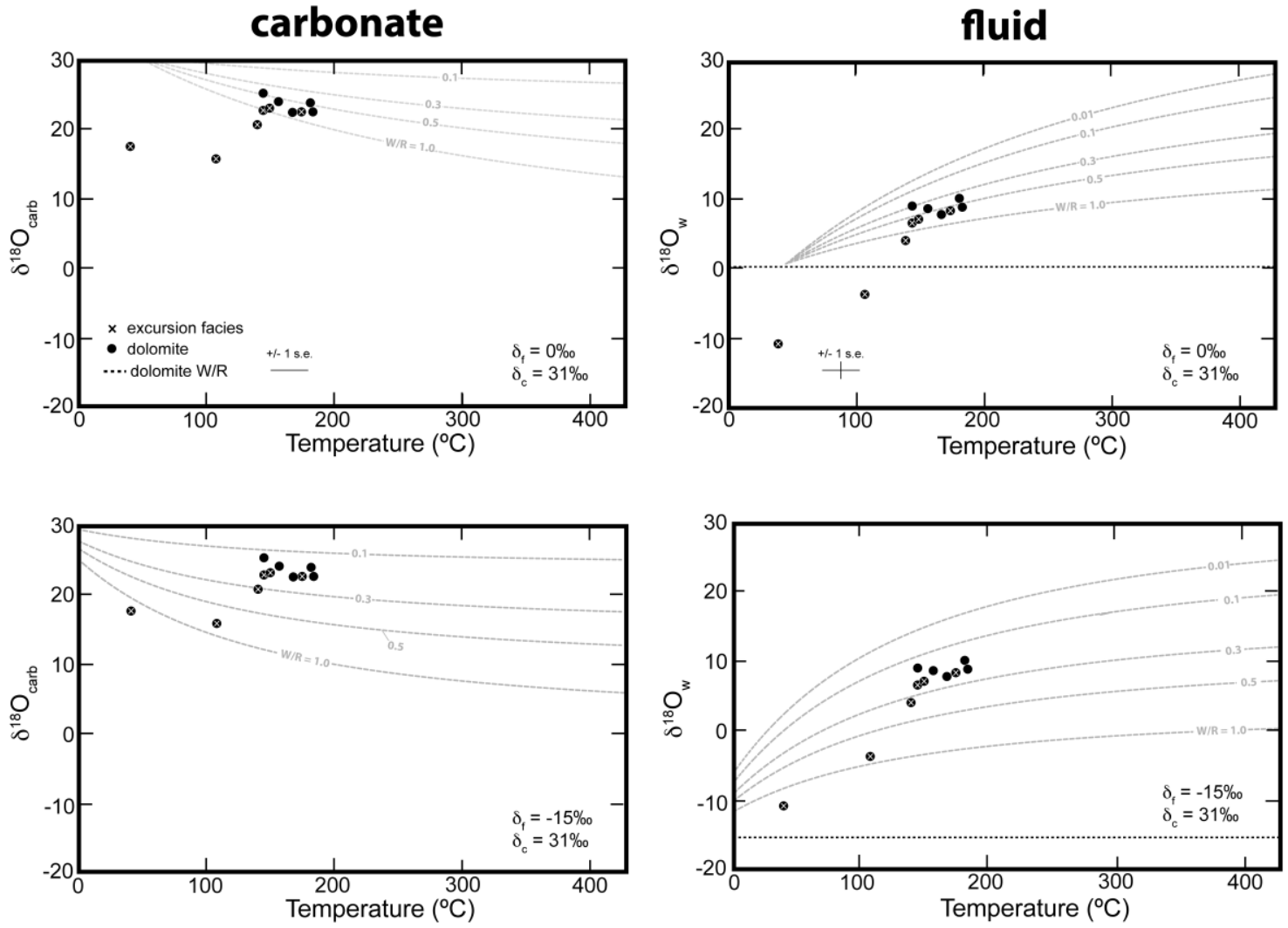
Figure 7

\section{South China}
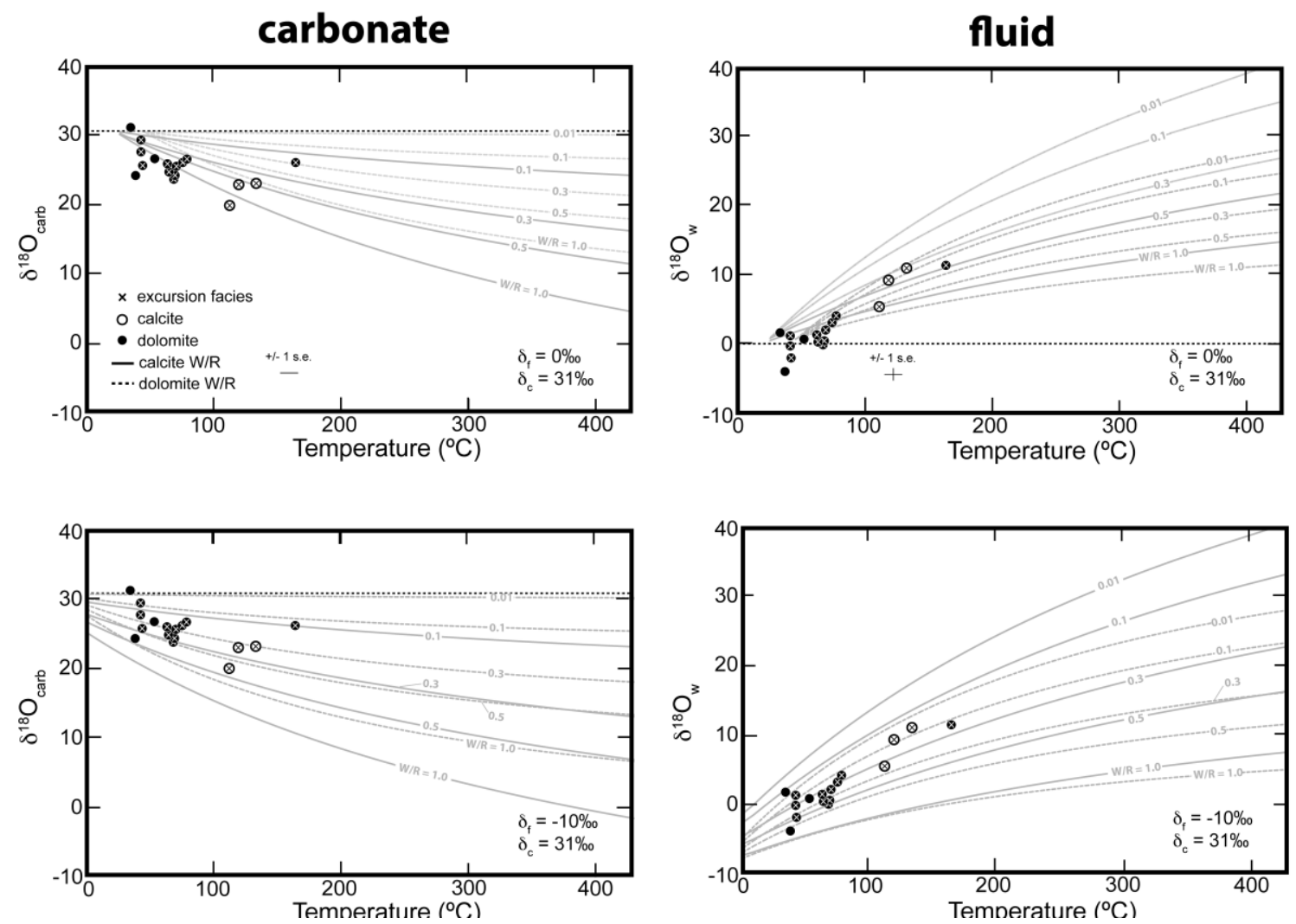
Figure 8
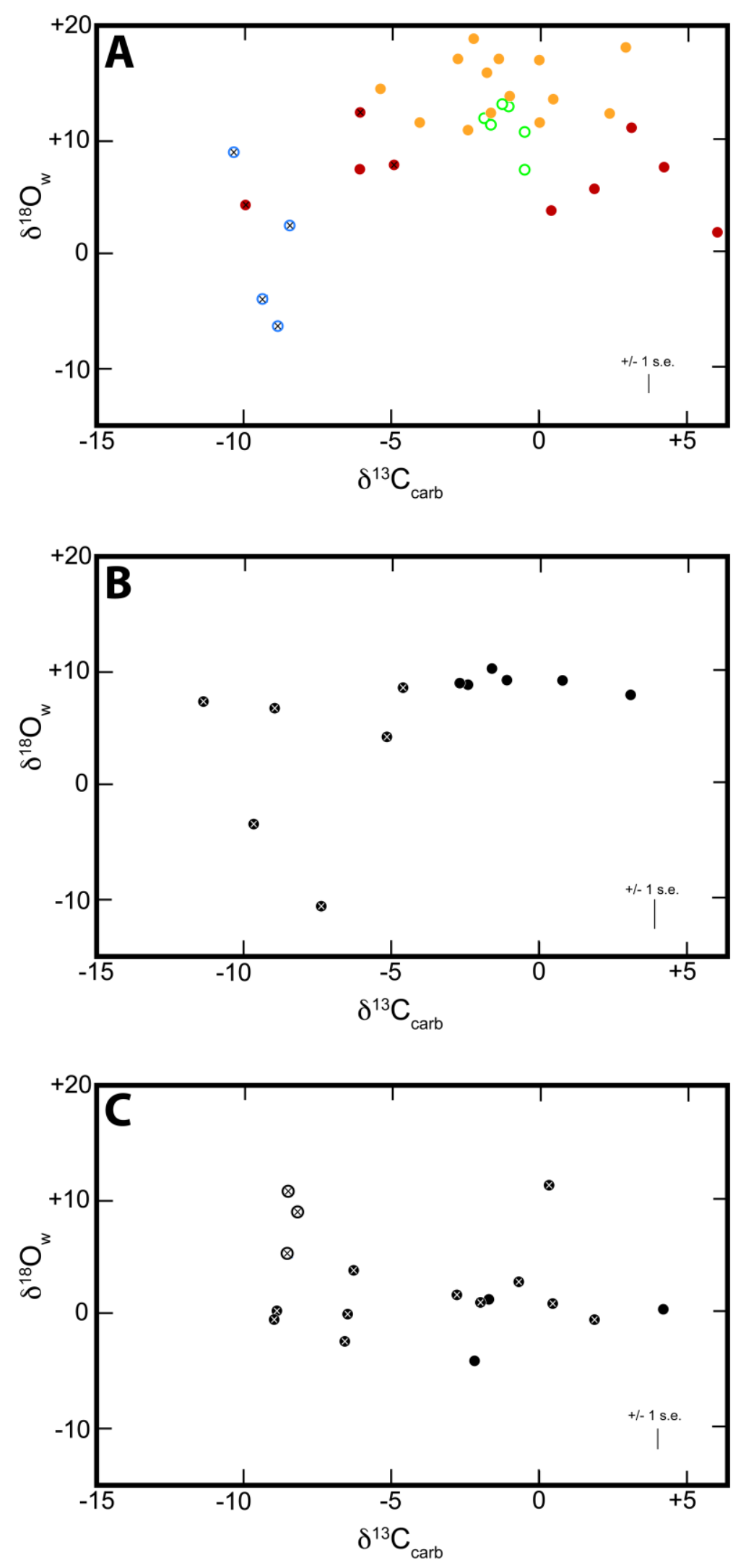
Figure 9
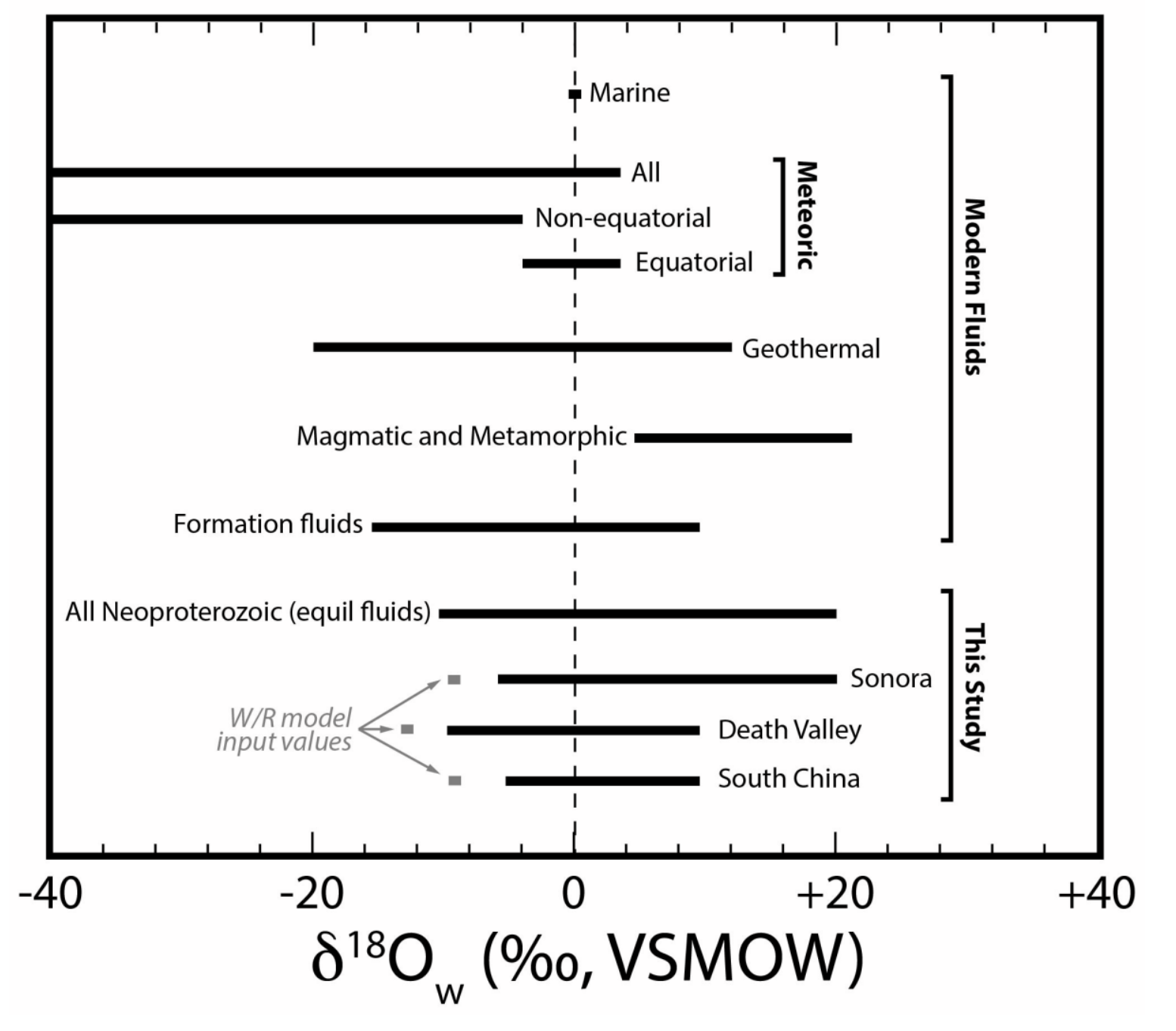